\title{
副睪丸を中心とした男子性器結核に就ての研究
}

\author{
新潟大學醫學部泌永器科教室 \\ (主任：楠隆光敎授) \\ 助手向川墽幸
}

\section{THE STUDY ON MALE GENITAL TUBERCULOSIS CONSIDERED FROM THE VIEW-POINT OF EPIDIDYMIS}

\author{
Toshiyuki Mukaiyama \\ From the Department of Urology, Niigata University, School of Medicine
}

(Director: Prof. T. Kusunoki)

副睪丸結核虫我々が最も多く遭遇する泌尿器科 的疾患の一つである. 從つて本疾患に關しては凡 ての方面皮ら既に充分に踞究されつくされて居る 豈であるふ，注意哚く調へると案外に等䦥に付さ れて，未だ，研究されていない方面か殘されてい る. 郎ち，第 1 にその臨床診斷の問題である．副 罯丸の炎症の場合に，急性の場合浊別として，慢 性或は亞急性の場合には，それが單純性のものか 或は，亦結核性のものかの制定は非常に困難であ る.のみならず，急性症狀を示す場合に於ても， 組織學的に檢索して見ると結核性副睪丸炎の像を 示す場合もある。第 2 には，系統的疾患の型をと る傾向の㯨阮て强い性器結核に於ける, 副睪丸結

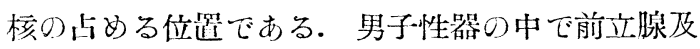

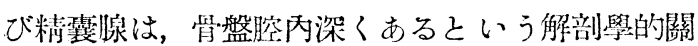
係, 及び臨床症狀の著明でない點から，臨床的に 目立つのは專ら副睪丸の結核のみで，前立腺及び

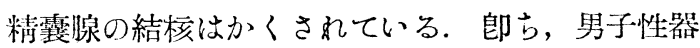
結核に於ける副罣丸と前泣腺及び精囊腺との關係 は, 丁度水山の水面上の部分と水面下の部分との 關係の如くであつて，臨床家は大き水山の一小 部分として水面上に出て居る副睪丸の綡化を見て 居る譯である。“從つて病理解剖の力而から男子性 器結核を詳練に調へる研究は多數あるふ，臨床的 の方面から男子性器全體に考えを及汇して調べた 㪷究は餘りない。

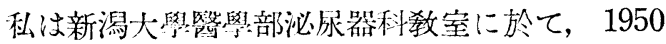
年 7 月小ら，1953 年 6 月迄，結核の疑いのある凡

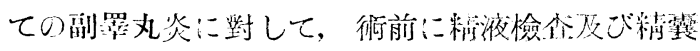

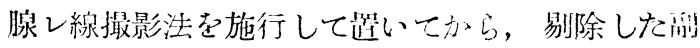

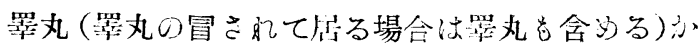

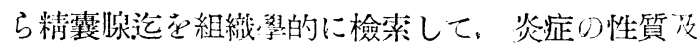
び病變部の變化る゙調べて又之等心所見を润前の精

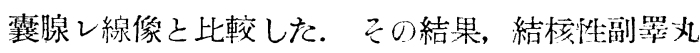
炎の疑いの濃厚副睪丸の慢性或は垔急性の炎症 に於て，結核性副睪丸炎の頻度，臨床的碑究であ

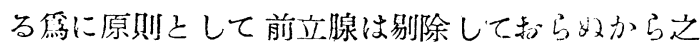
は除外して，罯丸結核の際に合併する中心部性器 結核の狀態及び中心部性器結核に於ける精霬腺し 線像の價值等，專副睪丸を中心乙して臨床的方 面より男子性器結核を政究した。更に若下の動物 實驗をも加えて，興味ある事實を得たので，立泫 報告する。なお，臨床上副睪丸結核之鑑别上大邵

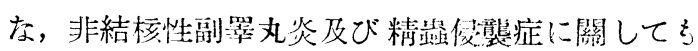
一言したい.

\section{I. 結核性副睪丸炎の手術々式に就ての 交獻的考察}

男子性器結核に對する手術は，從來は副㖕丸影

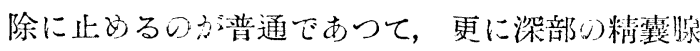
及び前立腺迄の剔除䋡り行われていながた。 その理内之しては，1）之等中心部性器結核は臨床

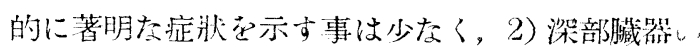

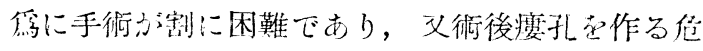
險があり，3）青非年者に多い本疾患に對して，己 の剔除は性生活の上に惡影響を及更ずすではない 小と云う危惧等が考え方れる。然し男子性器結核 
の.場合に中心部性器の結核䍜患率は $3 / 4$ 以上の高 率农示して们り，根治手術を目的上した場合に虽 然中心部迄の剔除が間題となつて來る.

副睪丸剔除䢖は1851年 Malgaigen により行わ

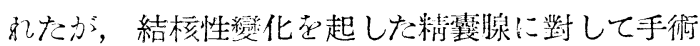

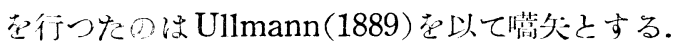
この後も一部の人澾により男子性器結核に對して

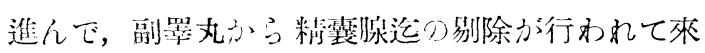
た. 郎占, Young, Whiteside, Qvinby, Dillon, Hinman, Voelcker, Villard 等は夫々の術式芭

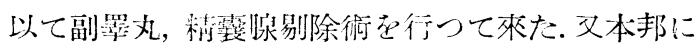

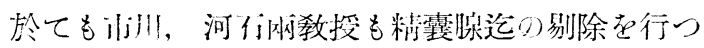
た事がある。然し性器結核に業する根治手術とし て理論上最も理想的咕副罻丸, 精囊腺, 前立腺全 剔除術经蜍り行われておらず，この方面の大家で

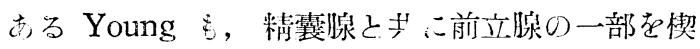

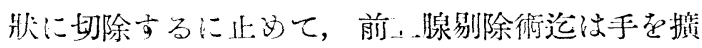
げなかつを，然るに今次大戰後に化學潦法を无分 に併用出來る時代こ拄り，ある人々埂に䢚にで 前立腺迄己剔除方る，郎ち黄の意味の性器結核の 根治手術と稱す心きものを断行している，郎ち， Staehler (1948) ○22例, Scardino et al (1950) 4 例, Jones(1951) の10例の報告が市り，又 Friedmann et al(1952)及び Baker and Graf(1952) 以前立腺結核口るに對する前立腺全剔除を 4 例に 施行している. 又 Silva de Assis(1952)は正中切 開法による精囊腺剔除術を弡表している.

本邦に於て蛙 1951年楠敉授が男子性器結核の根

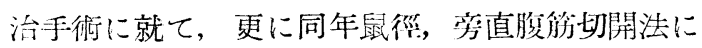
上万副睪丸，精囊腺剔除術!就て，交獻例に加え

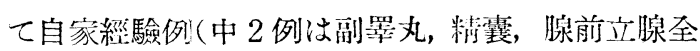
剔除）㦛げて，くわしく報告されている. 更に 1952年大森及び加虫は本法による副䍘丸，精霬腺 剔除術胥19例に施行している。

\section{II. 我敉室の手術例}

1950年 7 月水ら，1953 年 6 月迄口 3 力年間に於

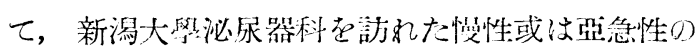

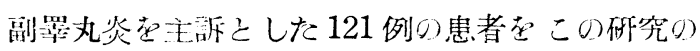
對稱としたが，この中手術を施行した患者は 119 例で，この內誶法第1表の通りである。向この中
第 1 表 119例の患者に施行した152回の手術々式

\begin{tabular}{|c|c|}
\hline 手 術 々 式 & 手術回數 \\
\hline 副睪丸 (睪丸) - 精囊腺剔除術 & 131 \\
\hline 副等 丸 (睪 丸) 剔 除 術 & 19 \\
\hline 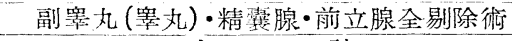 & 2 \\
\hline 合 計 & 152 \\
\hline
\end{tabular}

网側のものふ333例あり，賽驗に剔除した包數は 152 回である. 文前立椖肥大症と考えて剔除された標 本につき調愁の結果，結核の登明された例がある が,この研究からは除外した。

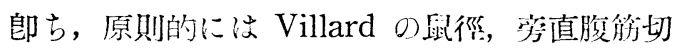
開法による副罢丸(睪丸), 糊露腺剔除術在施行し たが，19例は術前の諸檢省で中心部性器に結核性 變化が認められなかつたので，普通の副睪丸（睪 丸）剔除術に止めた。 なお62歲の 1 例，及び30歲 の前立腺直腸瘦を併㷋した1例の合計 2 例には， 下腹部正中切開に上る副罢丸, 精需腺, 前立腺全 剔除術を施行した。

\section{III. 結核性副睪丸炎の頻度}

剔除した標本152中 $151 に$ 就て，之組織㸚的に

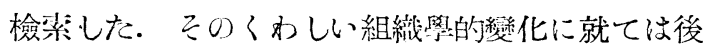
述する事にして，先す組織學的診斷より見た結核 性测睪丸炎り频度に就て述べる。

151 住の剔除標本の組織學的診斷は，第 2 表に 示す如くであつた.

郎ち，結核性副塄丸炎は全體の約 $3 / 4$ に當る 114 例(75.5\%)で, 殘り037例中33例(21.8\%) が單純

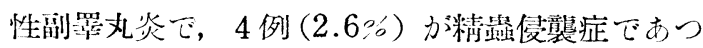
た.

次に組織學的に檢枯した 118 例の患者に就て， 臨床上の各方面から觀然して見よう。

(A) 年踰别

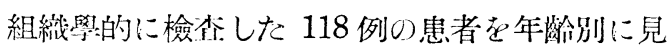
第.2表 151例の組織學的診穆

\begin{tabular}{|c|c|c|}
\hline 䛦＼cjkstart斷 & 例 $\cdot$ 數 & $\%$ \\
\hline 結 核 性 副 辠 丸 炎 & 11.4 & 75.5 \\
\hline $\begin{array}{c}\text { 非 結 核 性 副 睪 丸炎 } \\
\text { (韭特異性副睪丸炎 }\end{array}$ & $\begin{array}{l}33 \\
29\end{array}$ & 21.8 \\
\hline \{外傷性副鼻 丸炎 & 4 & \\
\hline 精 蟲 侵 襲症 & 4 & 2.7 \\
\hline $\begin{array}{c}\text { 註：精䖵侵襲症は，この他に } \\
7 \text { 列めつた。 }\end{array}$ & 荅に合位 & ものが \\
\hline
\end{tabular}


第 3 表 組織學的に檢查した 118 例の年虍別

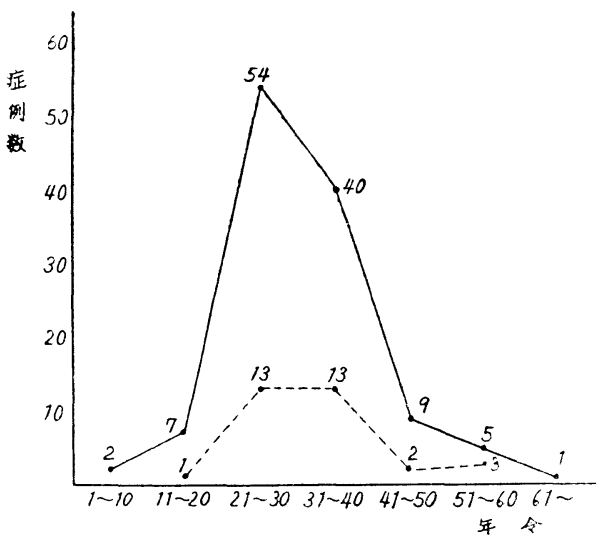

ると，第 3 表の如くである，估點線㹥非結核性と 診衒されたもの〉曲線である。

郎ち，20歲代及び30歲代が大部分を占め，合計 94例(79.7\%) となつている. 倚最低年㻌は 7 歲, 最高年岟は62歲で，共に組織學的には結核性副羁 丸炎之診斷された。

(B) 患 側 別

118例中單側症例は63例 (53.4\%)，网側症例55例 $(46.6 \%)$ で，單側症例中右側35例 $(55.6 \%)$, 左侧 28例(44.4\%)である.

(C) 性器以外の結核の合併, 特に尿路結核の合 併

尿路結核(腎結核) を合併したものは36例（30.5 $\%)$ ，その他の臟器の結核を合併するか或はその既 往歴のあるものは65例(55.1\%)であつた。. 又尿路 結核を合併した 36例中兩側性器結核症例は23例で 之は全网側性器結核症例 55 例の $41.8 \%$ に當る。な お尿路結核を合併した 36 例中組織學的には 3 例 (16.7\%)が非結核性副睪丸炎であつた。

(D) 性病 (淋疾) 及び外㑺の既往禁

淋疾の既往杯を有するちのは 14例で，この中組 織輿的に結核性副睪丸炎之診斷されたものは6例 $(42.9 \%)$, 文外賃の既往磨老有するも0は7例で この中結核性副睪丸炎と診斷されたるのは 4 例で あつた。

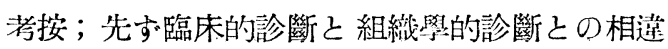
であるが，元來副睪丸結核の確實な診斷を臨床的

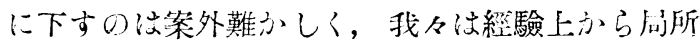
の所見, 性器外の結核，特に尿路結核の合併或况 その既往磨口有無，文び尿道ツベルクリン反應等 から診斷を下しているが，私が結核の相當疑わし いものにつき組織罗的に檢监した成績では，そい 約 $3 / 4$ のみ結核であつた。 又各症例に就て見て も，尿路結核足合併した副睪丸炎て，臨床的にも 相觉に結核性炎症を思わせた症例に於て，組織帠: 的に非結核性炎症である事が制つた症例がある小 と思うと，外賃後に丝急性に腫脹して來た副睪丸 炎ぶ血行性結核性副䍘丸炎であつとた云う譯で， 全くその臨床診斷の困難性を痛感させる.

次に臨床上問題となる事は，性器結核が他の結 核と同樣に系統的次患であり，肉側症例の多い事 である．私の症例に於ては 118 例中55例(46.6\%) が网側性であつた。光文獻的に見てみると， Kretschmer $039.3 \%$, Huntの63.6\%, Delore䏠 び Chalier $025 \%$, Barney $41.6 \%$, Ljvnggren 0) $14.5 \%$, Greenberger 及び Greenberger 6) $36.3 \%$ となており, 文剖檢例に於ては, Delore 及び Chalier $2 \%$, Greenberger 及び Greenberger は $70 \%$ そ報告している。文本邦交獻で岕 不川の32\%, 坂口・大森 $044.4 \%$, 河们・岡本心 $34.3 \%$, 古川・术村043.1\%, 明村・酒井・岡部心 $42.5 \%$ と, 大體 $1 / 3$ から年數近くが网側性である.

更に尿路結核0)合併率老見ると， Bachrach () $20 \%$, Barney-Watson 及び Elliott D 11\%', Young $050 \%$ 以, Wildbolz $071 \%$, Menville 及び Priestley $051.6 \%$, Seardino-Kelley 及び Scott $の 27.6 \%$, Greenberger 及び Greenberger の $28.1 \%$ とつており，本邦では小池・大森の53 $\%$, 坂口・大森 $034.6 \%$, 㠴川 - 卜村の $44.6 \%$, 川村・酒井・岡部の $51.5 \%$ \%つており，私の症 例では36例(30.5\%)であつた。

又興味深了思われる事は，尿路結核老合併した 36例中网側副睪丸結核例か：23例(63.8\%)に見られ た事で，之は全网側副罩丸結核患者の $41.8 \%$ に賞 る.なお尿路結核合併例中組織學的に非結核性副 睪丸炎子診斷されたものは 3 例(16.7\%)で，之识 いすれを單側症例に於て見られ，网側症例つ23例; 
はかす员多組織學的には，結核性副睪丸炎であつ t:

\section{IV. 組織學的檢索の成績}

男子性器結核の組織學的研究は臨床芜の間に於 ても現在迄に數多く雼されて來たが，之は殆んど 汸副睪丸のみに就ての砾究であつた。然し男子性 器結核の砄究に當つて，唯單に副睪丸のみの組織 祭的檢菜げけでは，丁度水山の水面上の一部分の 一を檢柆するの之同じであつて，男子性器結核の 全貌は更に深部迄檢索しなけ蜼つかか得ないも のである。

副睪丸から精囊腺及び 前立腺迄の研究は以前に 於ても行われて來をが，之等はいす况を剖檢例に 就ての檢索であつた。郎ち, Simmonds, Cunningham, Schultz, Sussig, Menville and Priestley, Barney, Medlar, Spain and Holliday 等, 文本邦に於ても稻田等の報告が見号れる。之に對 して臨木的に精垔腺迄の組織學的檢索の結果を發 表して居るのは，歐米では Scardino et al の4 列及び Jones の10例， 文本邦では市川及び等永の 11例，大森及び加島の19 例の報告等の小數例に就 ての報告があるばかりである。

私は男子性器結核を疑わしめた 119 例の患者に 對して原則的に根治手術を行い，この中の118 例 に就て剔除標本を組織學的に檢堂した。

なおこの研究に虽つては，新潟大學病理學㸚室 の赤槣呚授及び藤卷敉授の御懇篤な御指導, 御敉 示を頂いてお゙り，深甚なる謝意を表するものであ 万.

\section{(1) 檢峜材料及び檢查法}

118 例中雨側性のものが33 例あり, 從つて檢來 標本は151例であつを。 之等の標本に於て, 原则 として，i）副睪丸頭部，ii）副睪丸尾部, iii）精管 の中央部，iv）精管膨大部，v）精䨳腺の 5 部位に 就て, 又例外的に一緒に剔除した前立腺及び睪丸 に就ても檢夜した. 染色法としては，i）へマトキ シリン・エオジン染色，ii）結核菌染色及び iii) ワンギーソン氏染色を行い，更に場合により，iv） 鍍銀法它施行した。

(2) 檢枩成縝
第 4 表 114例の結核性變化を示した部位

\begin{tabular}{|c|c|c|c|c|c|c|}
\hline $\begin{array}{l}\text { 副睪丸 } \\
\text { 頭 }\end{array}$ & $\begin{array}{l}\text { 副睪丸 } \\
\text { 尾 部 }\end{array}$ & $\begin{array}{l}\text { 䄇管の } \\
\text { 中央部 }\end{array}$ & $\begin{array}{l}\text { 清 管 } \\
\text { 彭大部 }\end{array}$ & 精囊腺 & 症例數 & $\%$ \\
\hline$(+)$ & $(+)$ & $(+)$ & $(+)$ & $(t)$ & 23 & 20.2 \\
\hline (二) & $(+)$ & $(+)$ & $(+)$ & $(+)$ & 43 & 37.7 \\
\hline$(-)$ & $(+)$ & $(二)$ & $(+)$ & $(+)$ & 14 & 12.3 \\
\hline (二) & $(+)$ & $(-)$ & $(-)$ & $(-)$ & 8 & 7.0 \\
\hline$(+)$ & $(-)$ & $(-)$ & (-) & (-) & 4 & 3.5 \\
\hline$(-)$ & $(-)$ & (t) & $(+)$ & $(+)$ & 2 & 1.8 \\
\hline$(+)$ & $(+)$ & (二) & $(+)$ & $(+)$ & 2 & 1.8 \\
\hline$(+)$ & $( \pm)$ & $(二)$ & (二) & (二) & 1 & 0.8 \\
\hline$(+)$ & $(-)$ & $(\mp)$ & $(-)$ & (一) & 1 & 0.8 \\
\hline$(二)$ & $(+)$ & (一) & (-) & $(t)$ & 1 & 0.8 \\
\hline (二) & $(-)$ & $(-)$ & $(+)$ & $(+)$ & 1 & 0.8 \\
\hline (一) & $(-)$ & $(-)$ & (二) & $(+)$ & 1 & 0.8 \\
\hline$(+)$ & $(+)$ & $(+)$ & $(+)$ & & 2 & 1.8 \\
\hline$(-)$ & $(+)$ & $(+)$ & $(+)$ & & 2 & 1.8 \\
\hline (二) & $(+)$ & (一) & $(-)$ & & 1 & 0.8 \\
\hline$(+)$ & $( \pm)$ & $(+)$ & & & 3 & 2.6 \\
\hline$(-)$ & $(+)$ & $(+)$ & & & 2 & 1.8 \\
\hline$(+)$ & $(+)$ & $(-)$ & & & 2 & 1.8 \\
\hline$(-)$ & $(+)$ & $(-)$ & & & 1 & 0.8 \\
\hline
\end{tabular}

151 例中組織學的に性器結核が立證されたもの は 114 例(75.5\%)で，然らざるものは37例（24.5 \%)であつた。郎ち，臨床的に結核性病變が疑わ しかつた症例の中で $75.5 \%$ と，その約 $3 / 4$ に結核 が確證された。ここで, 結核及び非結核の症例に 就て，別々にその組織所見を述べる.

A. 結核例の組織所見

a）部位別：114例に於て結核性變化を示した 部位は，第 4 表の如くであつた。 なお，睪丸及び 前立腺に就ては後述する。

郎ち，檢查全部に結核性變化を見をるのは28例 (24.6\%)，一部分(主として副睪丸頭部)を除いた 他の部全部分に結核性變化を見をものは 51 例 (44.7\%) と，系統的疾患の完全されをものが多 かつた。これに反して一部分（主として副睪丸） のみにしか變化を見なかつをものは，僅かに15例 (13.2\%)であつた.

次に性器各部の結核䍜患率を見ると，第 5 表に 示した如くである.

郎ち，少數例であるから前立腺を除外すれば， 副睪丸尾部の $92.1 \%$ 最も多く，副睪丸頭部は最 も少くて $33.3 \%$ \%ている. 之を文獻的に見て 見ると，この殆んど凡ての報告が剖檢所見に關す 
第 5 表 性器各部の結核罹患染

\begin{tabular}{|c|c|c|c|c|c|c|c|}
\hline \multicolumn{2}{|c|}{ 部 } & \multicolumn{3}{|c|}{ 位 } & \multicolumn{2}{|c|}{ 檢查例數結核例數 } & \multirow{2}{*}{$\begin{array}{c}\% \\
33.3\end{array}$} \\
\hline 副 & 睪 & 丸 & 頭 & 部 & 114 & 38 & \\
\hline 副 & 暻 & 丸 & 尾 & 部 & 114 & 105 & $92: 1$ \\
\hline 䊀 & & & & 管 & 114 & 78 & 68.4 \\
\hline 精 & 管 & 膨 & 大 & 部 & 106 & 89 & 84.0 \\
\hline 精 & & 覆 & & 腺 & 101 & 87 & 86.1 \\
\hline 前 & & 立 & & 腺 & 2 & 2 & 100 \\
\hline 睪 & & & & 丸 & 14 & 8 & 57.1 \\
\hline
\end{tabular}

るものであそ. 郎ち， Simmonds の200例に就て

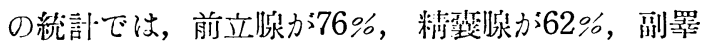
丸か5 $54 \%$ となつており，Schultz (125 例では，

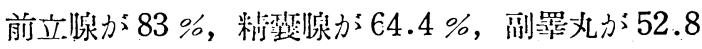
\%であり，文. Menville and Priestley 62 例で

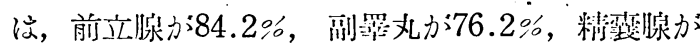

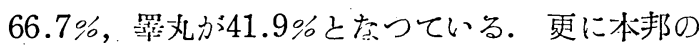
棌四の23例の統計では，前立腺が69.5\%，副蠋丸

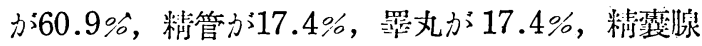
が 13.0\%の順之なつている，之等の文噳例を私の 例に比校して見ると，いすれも副睪丸の結核罹患 率は割合に低い率を示している。この相邀は，私 の)症例はあくまで副睪丸の炎症性腫脤を主訴とし て臨床例に就ての檢索であり，彼等の呼究は剖檢 例に就ての檢索である事によるものである.

（b）性器各部の組䄉像：次に 114 例の各部に於 ける組織燢的戀化を見てみよう。

1）副羂丸頭部：結核性變化の認められたもの は，第 5 表に示した如く，114 例中38例 (33.3\%) であつた．結核性病戀のなかつを76例に就て見る

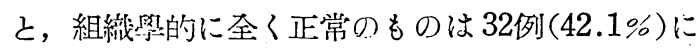
すぎす，他のものでは次の樣な變化が見られた。

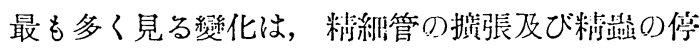
㲏，或はこの网者の合併したもので（第 1 圖)，そ の數は39例(51.3\%) と乎數以上にのぼつている.

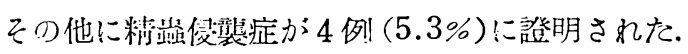
結核性變化のあつた 38例!に見られた變化は，閧 沉な乾酶性戀化を示すものが20例(52.6\%)，壊死 の著明なるのが 6 例(15.8\%)，纎維化の著明のも のが 6 例 $(15.8 \%)$, 增殖性變化を示すをのが5 例 (13.2\%)，之の他が 1 例であつた。 佾この他に， 結核性戀化の第に偑有の精細管を全く見ないもの
(第 2 圖)か29例(76.3\%)，血管を中心とした變化 (第 3 圖)が 3 例(7.9\%) に見られ，更に徏細管內

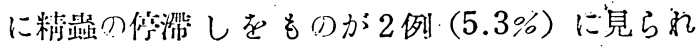
た.

2）副羁丸尼部：この部は性器各部中最も高率 な結核罪率を走していた。 郎ち，114 例中 105 例 (92.1\%)に於て結核性變化が見られ，しからざる ものは㑤かに 9 例 (7.9\%) に過ざなかつた。

結核性戀化の圭かつた 9 例の中で，全く正常と 思われるもの的 3 例(33.3\%)で，料細管の振張及 び粆显の倧洲，或はこの同者を合併したものが5 例(55.6\%)，粘液脜が 1 例(11.1\%)あつた。

結核性變化を認めた105例では; 展汹な乾酪化及 び壤死化を示したものが最も多くて77例(73.3\%) を占めて呞り，この中で精紐管の残つているすの

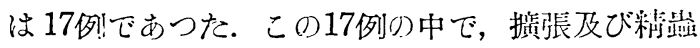
の停洲，或はその网者の合併したものが7例あつ な。、又興味ある事は, 全く乾酷性, 壇死性變化に 陷つてしまつた組䄉中に料㿻でけが残つているも のが 6 例あつた(第 4 圖). なお 3 例に精显促琵症 の合併像が見られた(第 5 圖).

3）銅管の中部(第 5 表)に示した如く，䊖管 の結核罪患率は性器中で副讟丸頭部，潈丸に次で 少く，114 例中 78 例(68.4\%)であり，且つ之の戀 化も多くは比較的輻度であつた。 これは战管の网 端，郎ち副䍗丸尾部及び精管膨大部が夫ィ $92.1 \%$ 及び $84.0 \% の$ 罹患率を示し，その戀化の程度の高 いのに比較して興味ある事と思われる。

結核性變化わ見られなかつた 36例中，全く正常 と思われるも0は19例(52.8\%)，粘膜下或は筋首 に細胞浸閵或は出血の見られたものが16例 (44.4 \%)，その他が 1 例(2.8\%)であつた.

結核性變化を認めた 78例では，粘膜下或は筂層 に變化のあるものが 19例(24.4\%)，(第 6 圖)，飞の 他の部位或は料管全體に變化のあつたものが59例 (75.6\%)であつた.なお，この他の曫化としては精 管上皮の變化が 21 例に見られた。郎ち上皮の脫落 したものが17例，破壊したすの及び屚平上皮化が 各 2 例であつた(第7圖). 文管腔內に乾酪性或い は壊死性物質のつまつをものが11例，その壊死性 
第 1 圖

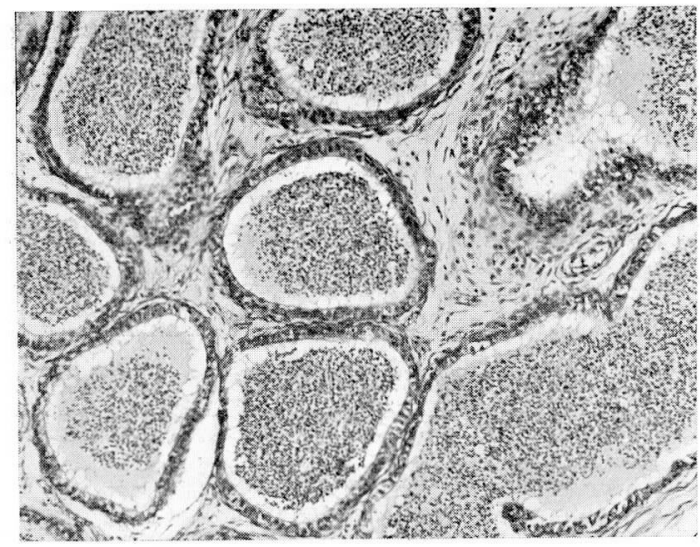

副睪丸頭部に於ける精細管の擴張と精䖵の停滯を示す。

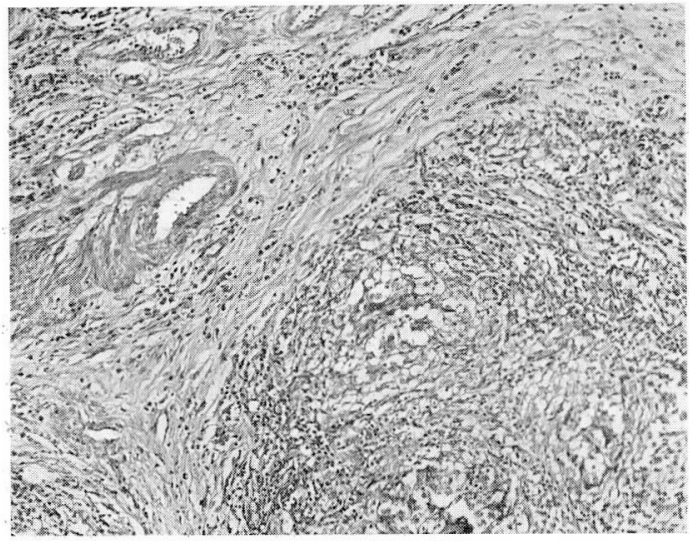

副罢丸頭部の血行性變化.

第 5 圖

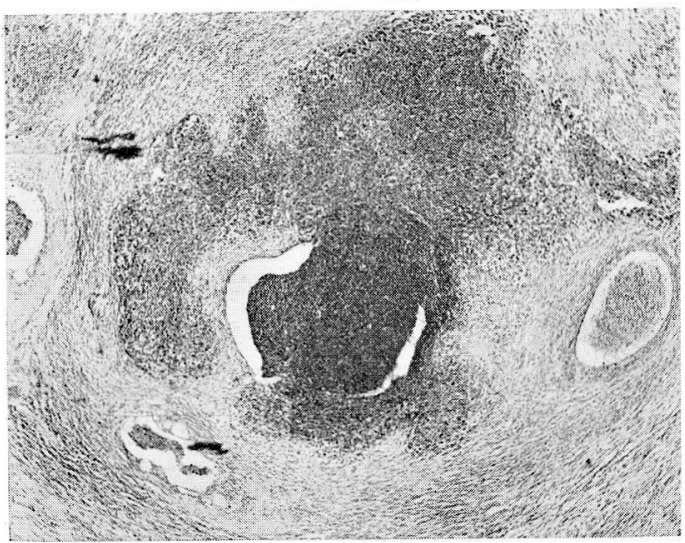

結核に合併した精蟲侵襲症。

\section{第 2 . 圖}

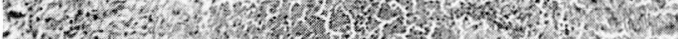

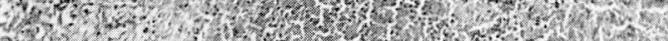

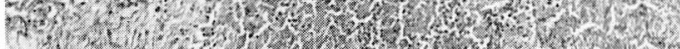

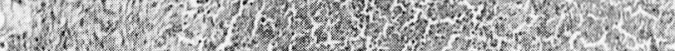

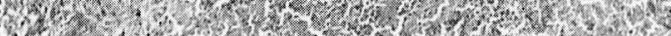

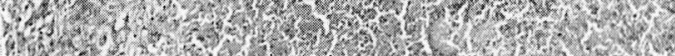

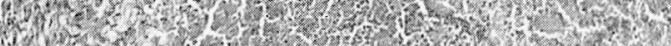
18x

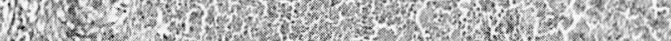

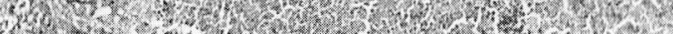

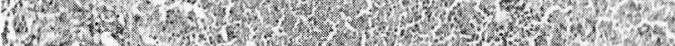

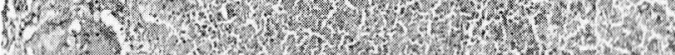

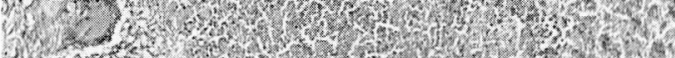

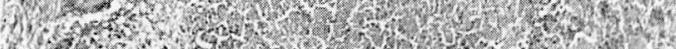

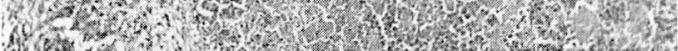
M.

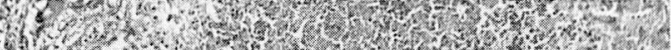

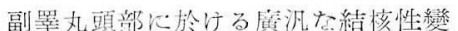
化老示す。精細管住見られない。

学 4 圖

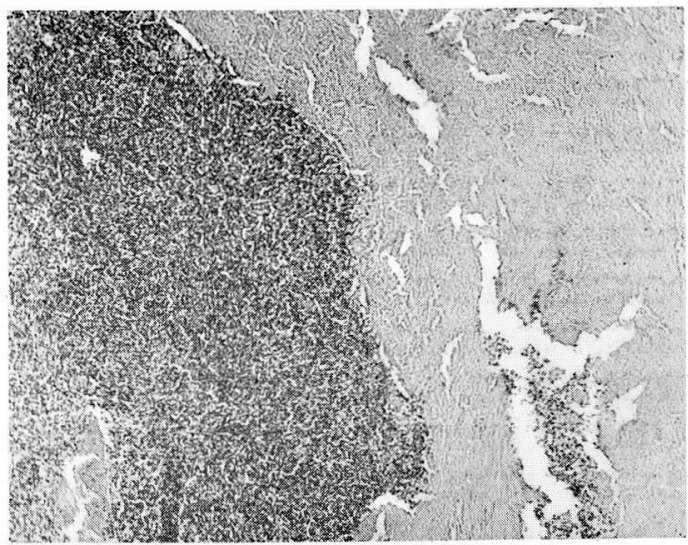

乾得化病临中心㙛存せる精䖵。

管 5 圖

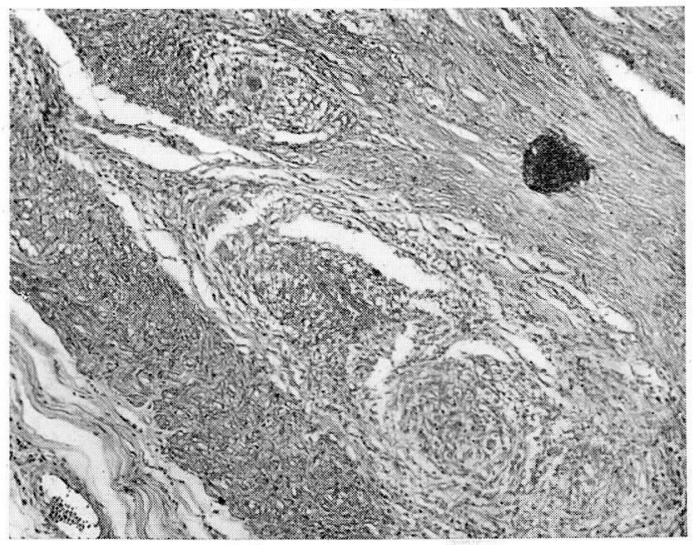

精管粘膜下の結核結節。 
第 7 圖

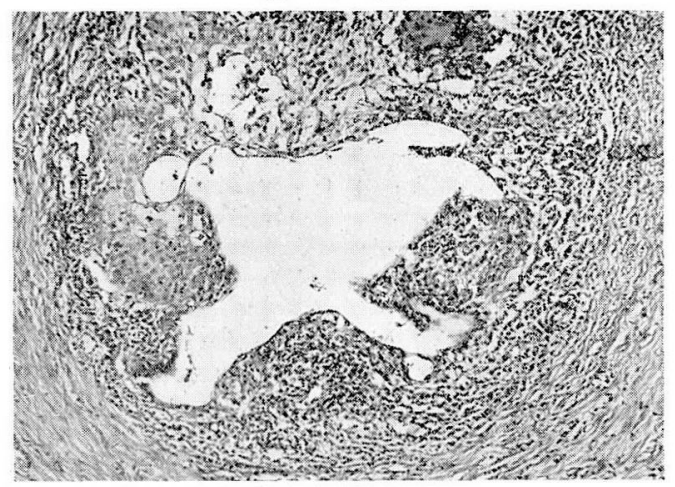

精管上皮の富平上皮化.

第 8 圖(1)

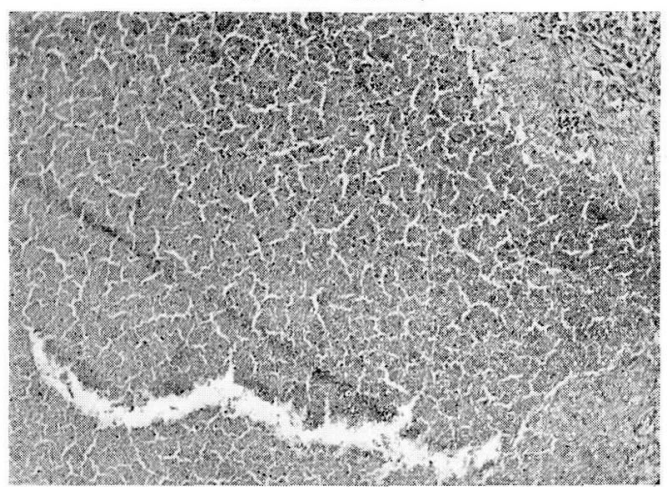

副睪丸の綧化

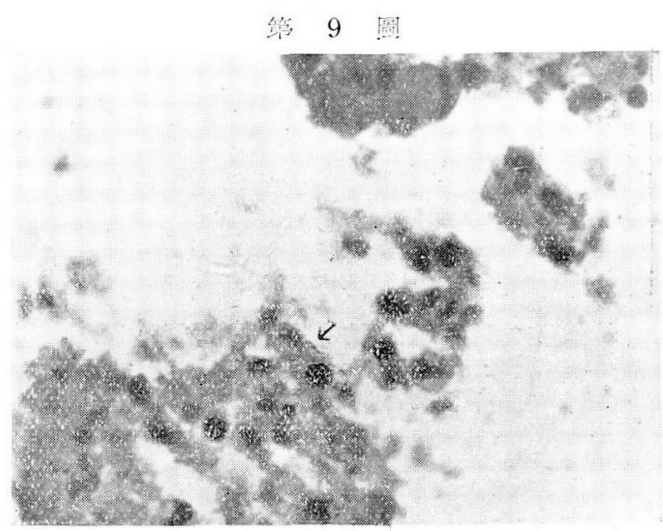

組織中の結核菌(臨床例) (矢印)

赫丸の紛化

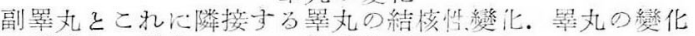

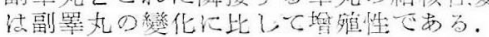

第 10 圖

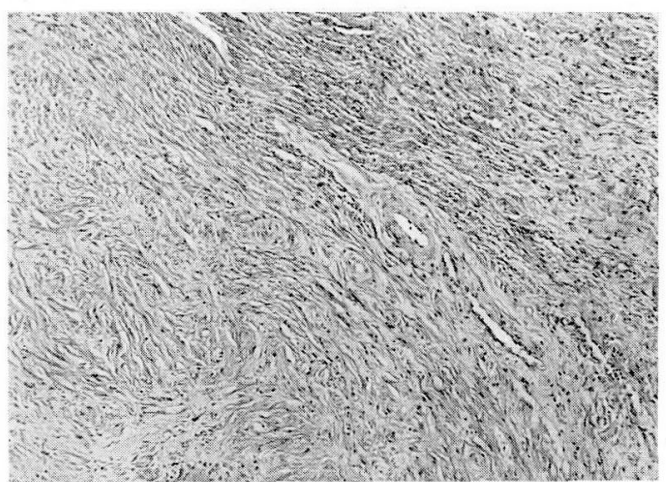

結核治瘵劑老使用した例の精

囊腺に於ける纖維化走示寸。

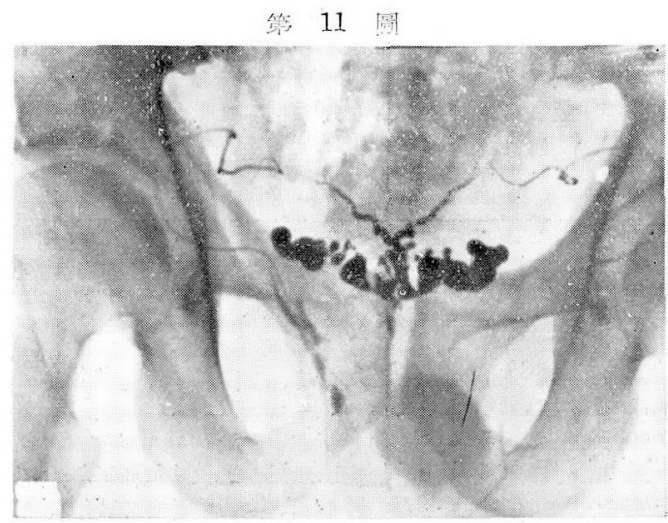

副睪丸にのみ結核性變化老認め, 中心部性 器以江琵狀を認めなかつた例のレ線像。 
第 12 圖

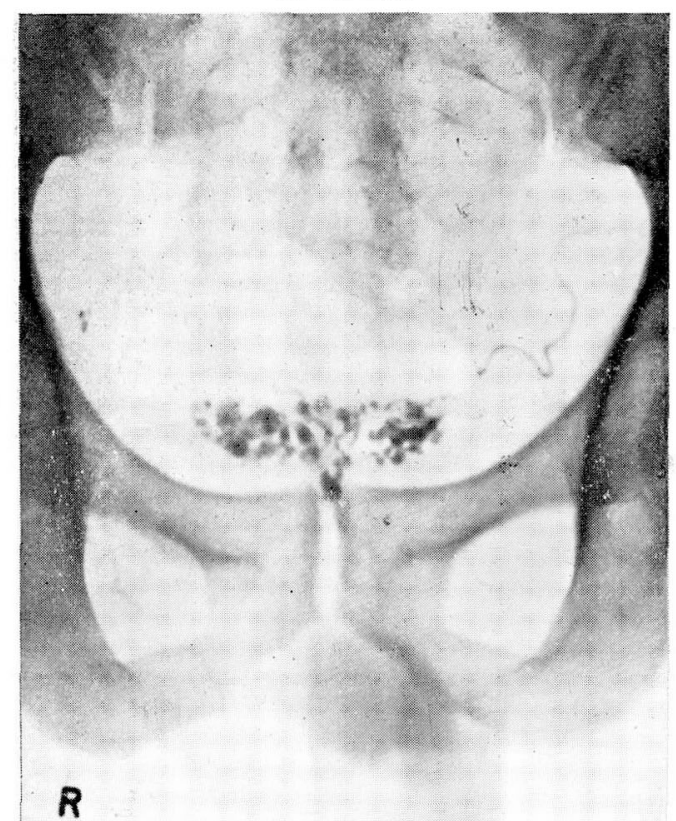

82

精慗腺に多數の結核結節を認めた例のレ線像。

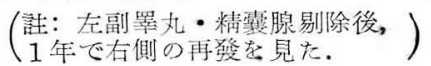

第 13 㘣

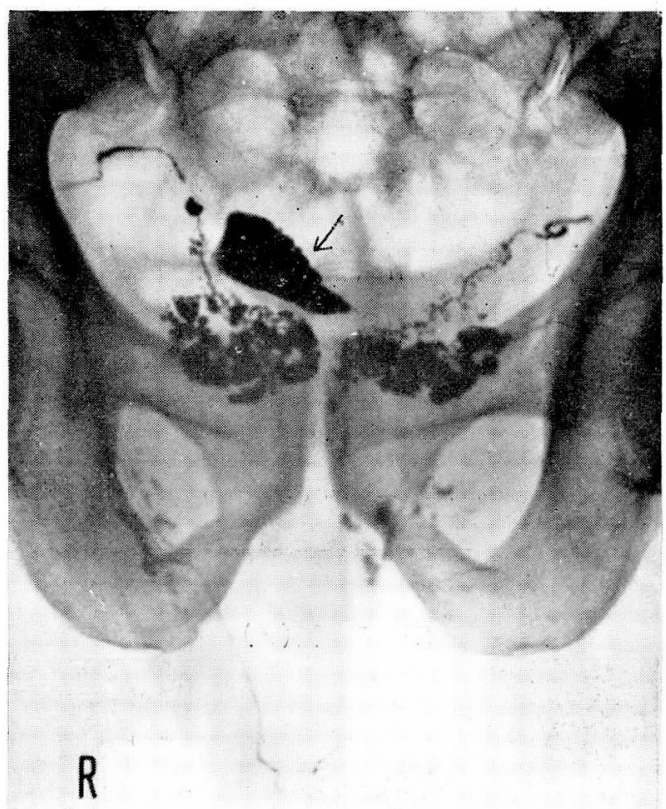

$32 \mathrm{e}$

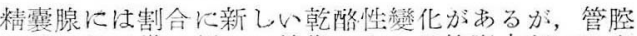
活殆んど正常の例のレ線像。な扔精管膨大部には多

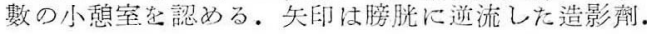

第 14 圖

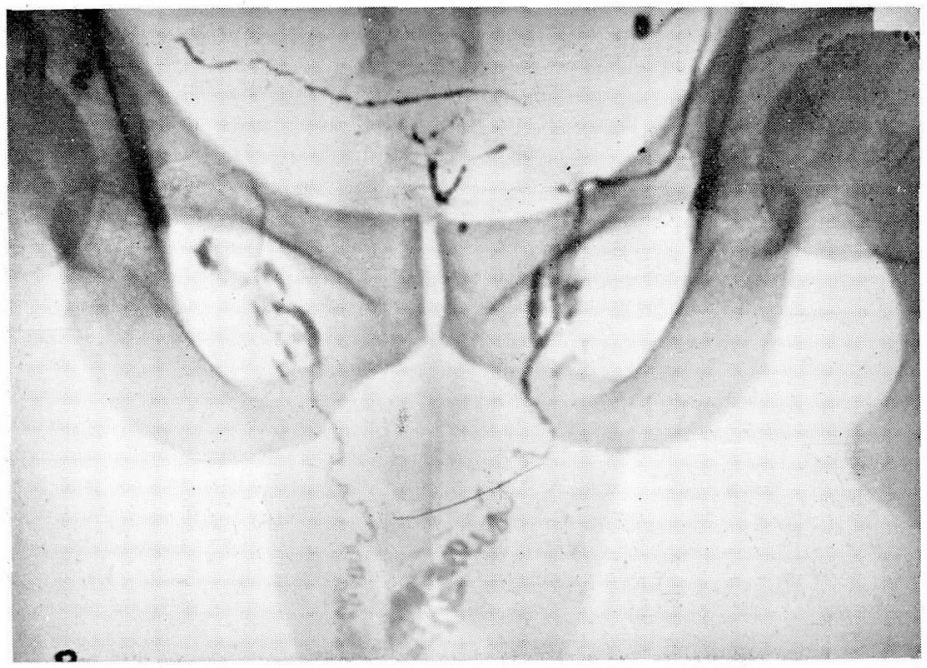

精囊腔腺の中心乾胳性物質がつまり, 乾降化の著明な病嶣が 到る處に見られた例.（註：臨林的には左副睪丸結核であつた

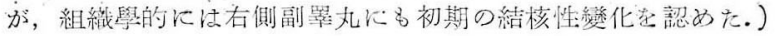


物質の中に精蚛のみ見出されたすのが2例であつ た.

4）精管膨大部：結核性變化を認めなかつた 17 例(16.0\%)の中で，全く正常之思われるるのは14 例 $(82.4 \%)$ で他の 3 例(17.6\%)では粘膜下或は䇗 層に細胞浸潤を認めた。

結核性變化を認めた 89例(84.0\%)で汶廣汎な乾 酪化或は壞死化走示すものが34例 $(38.2 \%$ ），瘢痕 化或は纖維化の著明のものが18例(20.2\%), 粘膜 下或は筋層に變化のあるものが16例(18.0\%)，閻 沨な肉芽形成を示すをのかi13例(14.6\%), 其の他 の變化を示すものが 8 例 $(9.0 \%$ 台 であつた。佮管 腔に乾酪性物質のつまつたものが7 例, 乾酪性物 質中に精蛅の見出されたものが1例なつた。

5）精霆脉：第 5 表に示した如く，101例中結

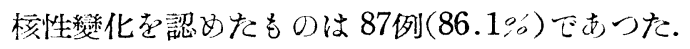
結核性變化を認めなかつた 14例(15.9\%)の中で, 組織學的に全く正常と思われるもの招10例，胍管 珎圍の細胞浸潤か： 1 例，其の他が 3 例となつて唇 る. 結核性變化を認めた87例では黄沉な乾酪化或

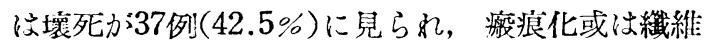
化う２2例(25.3\%)，粘膜下或は筋層の變化が11例 (12.6\%)，增殖性變化を示したものが10例（11.5 \%), 廣汎な肉芽形成を示したものか７例 $(8.2 \%)$

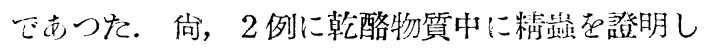
た.

6）前立腺：前述した如く，62歲の 1 例及び30 歲の前立腺, 直腸瘦を形成した 1 例の合計 2 例に 副睪丸から前立腺迄の全剔除を行つたか，前立腺 の＼cjkstart組織像はいすれも結核で，前者は廣汹な乾酪性 變化を示し 固有の腺組織は全く見られなかつた。 後者では一部に腺組織を認めたが，それ以外の部 浽乾酪化の傾向の强い大小の結核結節で占められ ていた.

7）睪丸：除睪術，或は牛除睪術を行つたもの 〉中14例に就て睪丸の變化を組織學的に檢索し, 特に之とこれに接する副睪丸の變化とを比較して 見た.

罣丸に結核性變化を認めたものは 8 例( $57.1 \%)$ で南つた。この8例の中でこれに接する副睪丸の
變化に比較して增殖性の傾向の强いもの（第 8 圖)が4例，网者の間に等異がなく，共に乾酪性變 化を示したものか４例であつた．郎ちこの事實は 䀞丸は副睪丸に比較して，結核に對して抵抗性うシ 强い性質を示す一つの現象と考えられ興味深い。

考按; 性器各部に於ける變化を通靦して, 次の， 諸點が興味深い。

1）㮽細管の態度：尿路及び腸管の樣な管腔臟 器に於て通過障碍のある際には，それより上部管

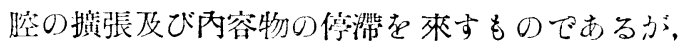
同㥞の變化が互に管腔性連絡のもとにある性器相 互の間にも見られた，郎ち料管或は副睪丸尾部の 結核性變化による通過障碍のある祭には, これよ り睪丸部にある精細管の擴張及び精量の停滯が見 られるもので, 私は副睪丸頭部では41例に, 同尾

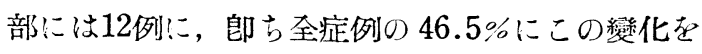
認めて后る。兒方を換えれば，精細管の撗張及び

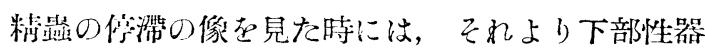
に通過障碍があると考えて上い譯である。

2）精管の變化：次に興味哚く思われるの精 管の戀化である．從來結核性副睪丸炎の診斷法之 しては精管の珠數狀腫脤が有力な症狀こされてい るが，實際に私の調心゙た處では，档管の結核羅患 率は68.4\%で，之は副睪丸から料露腺迄の間では 副睪丸頭部に次ぐ少ない罹患率である. 又この變 化も他部に比して一般に刺度の場合が多く，网端 郎ち精管膨大部及び 副睪丸尾部が高度の乾酪性變 化を示す例に於ても，精管は僅かに粘膜下或は筋 層に慗度の變化しか見ない場合が少くなかつた。 從つて粘管に觸知し得る程度の結節形成のあつた ものは數例にすぎず，從來診斷上大切だとされて 居を精管の珠數狀腫脹はかえつて例外的であると さ元云い得る。

(c) 网側性性器結核例及び珡結核合併例に於け 万變化：爾側性性器結核の53例及び腎結核を合併 した33例に就て, 网側の性器間或は精鼠腺乙副睪 丸との間に，組織學的變化の上に如何なる關係か： あるを調べて見た。

1）网側性性器結核：53例中腎結核を合併した 24例は，筒結核を合併した症例に含めて後述む 
る。腎結核を合併しない29例中爽側を同時に剔除 した17例に就て, ミの网側性器の變化を比較して 見を、网者の間に新舊の宾のあるものは7例で, 殘りの10例には新舊の嚄は認められなかつた。

次にこの29例の中で，病桼の變化から考えて精 囊腺より副睪丸に變化が波及したと思はれるもの 冲17例(58.6\%)で，この中管腔性のものが5例， 粘膜下或海等層支通して波及したるのか４例，淋 巴行性のものが 4 例で，殘りの 4 例忟不明であつ を. 又副睪丸より精霯胍に變化の波及したものは 2 例 $(6.9 \%)$, 血行性の變化のみのものか１例(3.4 ○）で，殘りの 9 例はいずれが先かは不明であつ t.

2）腎結核を合併した33例中，精鼠腺から副罢 丸に變化が波及したと考えられるものは16例 (48.5\%)，副睪丸より榡雯腺に波及したと考えら れるものは 4 例(12.1\%), 殘りの13例(39.4\%)は いずれが先か㥙不明であつた。

（d）感染經路：性器の中で何處に血行性或は尿 路から感染が起り, 又性器相互間にぼの樣にして 感染が蔓延したが臨床例の剔除標本から判定す る事は非常に困難で全く不明の場合が少くない。 茲にこれ等感染經路が朧氣ながらつかみ得た86例 に就て見ると第 6 表の如くである.

郎ら色々の感染經路の組合せがあるか，粘腺下 或以筋層を通して波及したと考元られるものか最 ち多く，28例(32.6\%)であつた。 そして明らかに 血行性子認められた症例は，その變化が副羁丸の 頭部或は尾部に限局して赝たものの中の16例，郎 ち18.6\%に過ぎなかつた。これ等の事實は副睪丸 結核の多くのものは中心部性器結核からの二次的

第 6 表 86例の感染或いは波及經路

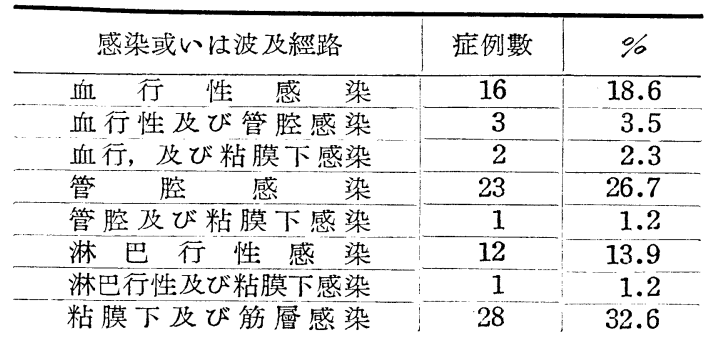

變化であつて，一次的血行性變化は比較的少ない 事走示して居る。

（e）組織內の結核菌：結核菌染色死行つた標本 に就て，性器各部に於的組織內の結核菌の分们 狀態を調べ，更に成熟家鬼を用いて之に血行性に 結核菌を注射して剔除した性器各部の結核菌の分 们狀態を臨木例と比較して見た。

1）臨床例：結核菌染色をほぼこした標本を， 普通の鏡檢により結核菌の分犾狀態をしらべた。 之の結果 18例に於て菌を證明し得た。この18例中 2 カ所に菌を證明した例か４例あり，從つて結核 菌を證明した部位は合計22カ所上なる。々の部位 は，i）副睪丸尾部が12例，ii）精管か４例， iii) 精管膨大部か３例，及び iv) 精霅腺が 3 例で，睪 丸及び副睪丸頭部に結核菌の見出されたるのは 1 例をなかつた。

同一例で 2 カ所に發見した 4 例は，副睪丸尼部 と精管に設見したものが 2 例，副睪丸尾部々䊑管 膨大部及び料管膨大部と精垔腺に發見したものぶ 各 1 例であつた。

i）副睪丸尼部：結核菌を證明した 12例の中で 單核白血球の浸㵎の割合に强心壊死病笨中に見出 されたもの(第 9 圖)が 3 例，壞死或乾酪病巢の 周園の白血球浸㵎のある 部位或洗類上皮細胞中に 䝢見したものが7例，精細管壁に近い結節中に弡 見したものが 1 例及び血管周圍の結節中に見出さ 机をのが1例であつた。

之等の例では，組織の中心部の變化中よりも遑 縁に近い變化の中に發見したきのが多く7例が うであつた.

結核菌を證明した 12例中組織祭的に精細管と沙 全く關係がなく毛絒血管を中心として發生して 居る, 郎ち血行性感染と思われる例は2例で, 残 りの10例はいすれも廣義の下行性感染の例であつ た.

ii）精管： 4 例に結核菌を證明したふ，血管を 中心とした變化の中に見出したものは 1 例もなく 管腔內の壞死性物質中に見出されたものが 1 例で 他の 3 例はいすれも粘膜下或は筋層の結核結節中 に發見した。 
iii）精管膨大部：結核菌を證明した 3 例は，管 膑內心乾酪性物質中に 1 例，粘膜下の結核結節中 に2例證明した。等はいすれも廣義の下行性感 染上思われる例であつた。

iv）龂囊腺：結核菌を證明した 3 例の中で，血 行性感染を思わしわを症例は1例もなく，中央部 の乾酪性變化の中に見出されたものが 1 例, 壞死 病集の周園の白血球浸潤のある部に見出されたも のお゙ 2 例であつた。

2）動物實驗例：7 匹の雄の成熟家鬼存用いて 結核菌浮游液を膜部大動脈に注射してから性器を 剔除して性器各部に於ける結核菌の分布狀態莸調 べた。なお結核菌を注射してから性器を剔除する 迄の時間は15分，30分，1時間，5時間，24時間，

5 日及び 10 日であつを。

i) 罣丸：7例中 4 例(15分後，30分後，1時間 後及び 24 時間後の各例）に結核菌を證明した。な おこの證明した場所に就ては，特别の部位的の考 異仿なかつた。

ii）副睪丸頭部：7例中 1 例(30分後の例)に血 管の周園に僅かに結核菌寺證明した。

iii）副睪丸尾部： 7 例中 4 例(15分後，30分後， 1 時間後及び 5 時間後の各例）に結核菌を證明し た.この 4 例中組織の中央部に近い處に菌を見出 したものが1例，割合に邀縁に近い部に發見した ものが 3 例であつた。.なお血管中には 1 例も發見 し得なかつた。

iv）精管：7例中結核菌を證明したるのは 1 例 もなふつた。

v) 精䨳腺： 7 例中 1 例(30分後の例)に被膜の 近くに僅かの菌を證明した。

vi）前立腺：7例中 5 例（15分後, 30 分後, 1 時間後, 5 時間後及び 5 日後の各例)に結核菌を證 明した。この5例中 2 例は被膜の近くに，他の3 例は被膜及び中耂部の近くに結核菌を見た，

考按; 臨床例にけ於る結核菌の墢見部位と動物 實驗のそれとを一括すれば，第7表の如くであ 万。

郎方動物實驗で血行性に結核菌が㑠入する頻度

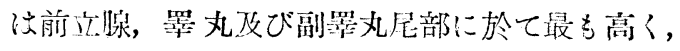

第 7 表 臨床例及び動物賽驗例の結核菌の發見部位

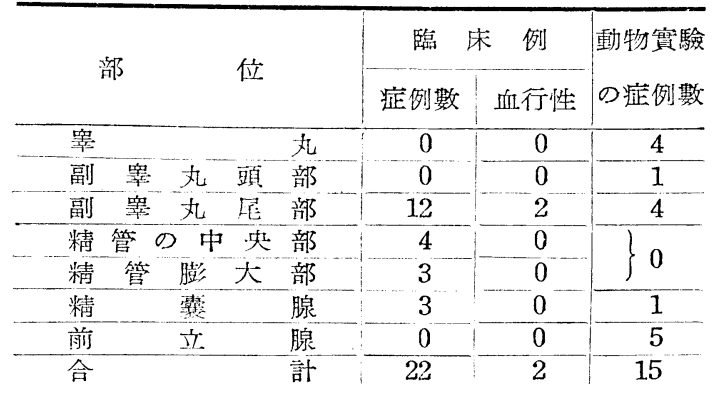

副睪丸頭部及び粡都腺が之に次ざ，精管では結核 菌を發見して后ないのに對して，臨床例では結核 菌の最も多く㻐見した部位は副睪丸尾部で，精管

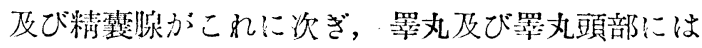
全く發見されていない，又臨床例で明らかに血行 性感染の潑明されたものは22例中鏵かに2例にす ぎない。この事實は，一方では性器の結核菌に對 する抵抗性が各部位により異なるから，血行性結 核の結核菌の偆入率と䍜患率とは平行しない事を 示している. 例えば睪丸には血行性に菌は非常に 伩入し易いのであるか，抵抗性の强いために，病 變は起りにくい．私の臨床例では睪丸變化がそれ に接する副罢丸の變化よりも增殖性のものが多か つたのもこのためである．他方臨床例で精管に多 數の結核菌を證明した事は，臨木的には，管腔性 感染が性器結核で重要な役割を演じている事を物 語つている.

（f）結核治療劑尼用いた場合の性器結核の組緎 像の變化：今次大戰後抗生物質の進步乙共に結核 治療劑も長足の進步をとげ，泌尿性器の結核に對 しても盛に用いられる樣になつた。泌尿性器結核 に對する本劑の臨床的效果に就ての報告は, Herman (1949), Taylor (1949), Lattimer et al (1952)等, 又本邦に於ても门沁川, 大越(1949) の報告 等少くない. 然し本劑を併用した場合の性器結核 の組織學的變化在追求した報告は案外少なく, 本 邦では僅かに1950年の赤崎呚授等の3 例の剖檢例 の報告及び 1952年の一井の6 例の臨床例の報告以 外にはない㥞である。

私は性器結核の患者の中で 14例に術前出來得る 
第 8 表 結核治療融造使用した14例の組織像

\begin{tabular}{|c|c|c|}
\hline 症例 & $\begin{array}{l}\text { 使用藥品名 } \\
\text { 及文びその量 }\end{array}$ & 織 \\
\hline 1 & S.M. $10 \mathrm{gm}$. & $\begin{array}{l}\text { 結節の周圍に圓形細胞浸潤著 } \\
\text { 盟. 巨細胞の形態には戀化忍 } \\
\text { 見られなな. }\end{array}$ \\
\hline 2 & S.M. 30gm. & $\begin{array}{l}\text { 巨細胞，圓形細胞は瘦せてて來 } \\
\text { て居るが治癒した所見はない. }\end{array}$ \\
\hline 3 & $\begin{array}{l}\text { S.M. } 40 \mathrm{gm} . \\
\mathrm{TB}_{1} \text { 1日 } 100 \mathrm{gm} . \\
6 \text { 力月間使用 }\end{array}$ & 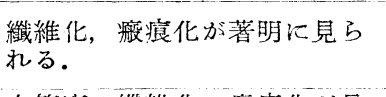 \\
\hline 4 & S.M. $15 \mathrm{gm}$. & $\begin{array}{l}\text { 中等度の纖維化，㓔痕化が見 } \\
\text { られる。 }\end{array}$ \\
\hline 5 & S.M. $10 \mathrm{gm}$. & 殆んど變化がない。 \\
\hline 6 & S.M. $15 \mathrm{gm}$. & 中等度の䋐維化が見られる。 \\
\hline 7 & S.M. 20gm. & $\begin{array}{l}\text { 乾䧄化した處が少くなり，纖 } \\
\text { 維化が見られる。. }\end{array}$ \\
\hline 8 & S.M. $5 \mathrm{gm}$. & 㱠んど變化がない. \\
\hline 9 & S.M. $10 \mathrm{gm}$. & 輕度の纖維化が見られるのみ。 \\
\hline 10 & S.M. 20gm. & $\begin{array}{l}\text { 纖維組織により病巢が包まれ } \\
\text { て居る. }\end{array}$ \\
\hline 11 & $\begin{array}{l}\text { P.A.S. } 50 \mathrm{gm} \text {. } \\
\text { S.M. } 5 \mathrm{gm} \text {. }\end{array}$ & 殆んぞ變化がない。 \\
\hline 12 & S.M. $10 \mathrm{gm}$. & 中等度の緎維化が見られる。 \\
\hline 13 & P.A.S. $100 \mathrm{gm}$. & 殆んど變化がない。 \\
\hline $\begin{array}{l}14 \\
\text { 牲 }\end{array}$ & S,M. 10gm. & 铱死が少ない・ \\
\hline
\end{tabular}

限りの結核治療劑を投與して，その後で副咢丸か ら精䨳腺迄の剔除を行い，剔除標本に就て組織學 的方面から本劑の性器結核に龂する效果を檢討し て見た。各例に於ける使用藥品名, 使用量及び組 織學的所見は第 8 表の如くである.

郎ち，纖維化の見られ艺をの（第10圖)方 6 例， 痗痕化方 2 例，細胞の變化を見だのが 1 例であ つたが，治瘉した像は1例も見られなかつた。文 ストレプトマイシン使用後にも 3 例 $(2$ 例は $10 \mathrm{gm}$, 1 例は15gm)では組織內に結核菌を登明した。こ れ等の事實は，赤䐀敎授等の經驗と全く一致する もので, 化學療法は性器結核には程極的の治癒效 果のない事を示している.

B. 非結核性副睪丸炎の組織所見

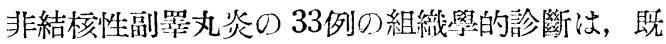
に第 2 表に示した如く，非特異性副睪丸炎が29例 及び外傷性副睪丸炎が 4 例であるか，この他の数 化としては，精霖腺に非特異性の炎症を認めたも のが15例，精囊腺に多數の小霆胞を形成している ちのが 2 例であつた. 又精管の變化としては, 粘膜 下或は筋層に細胞浸潤を見をものが6 例あつた。

郎ち，非特異性炎症の場合にも，全く結核性の
場合之同樣に，そ0炎症性變化力棌統的に性器各 部に及んでいる。更に炎症性變化は結核の場合之 同じく，精管の粘膜下，或は筋層に多く認められ た。要するにこれ等の事實虫, 性器の炎症性變化 方，その病原菌の如何を問わず，一樣に精管の粘 膜下或は衫層在介して系統的炎症に撗る特色のあ る事走示している.

C. 粘䖵侵裂症

精站が精細管周圍 の間質(主として副睪丸)に促 人すると一種の肉芽組織を發生することは，1924 年にOrsosによつて始めて記載された。これふふ今

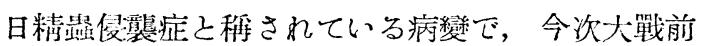
迄は一般の注意をしかなかつた眔にその報告は非 常に少なく，僅かに1924年のOrsós に續いて1931 年に Oberndorfer, 1624 年に再び Orsós, 次で 1944年に中內義夫と合計 4 例を 數えるのみであつ た。然るに大戰後，先つ1947年に Sternberg and Strausがその1例を報告したのに始まり，1949年 には米國の Army Institute of Pathology から Friedman and Garske が12例を，又スカンジナ ビヤからは Cronquistが7例の經驗を發表してか ら我國でもこの疾患が一般の注目する處となり， 1951年㸚室の阿部禮男の發表以來，阿部禮男・向 山敏幸(1952)，大森周三郎・齋藤英一(1952)，門

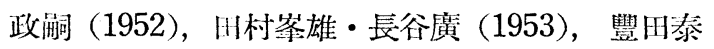
(1953)，坂野於鬼・松本忠夫・手束估 (1953),

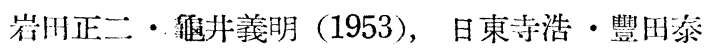
（1953)等の報告があり，この數は既に10例以上と なつている。

又外國に於ては，乏の後 1953 年の Rieger and Fuller の症例献告芭數え得る.

この研究の對照となつた 151 例の中に，組織医

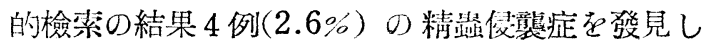
た。この他に結核に合併して見られた7例がある から合計すると11例(7.3\%)の多數に上つた。 友 お結核例は 114例であるから，副睪丸結核では 6.0

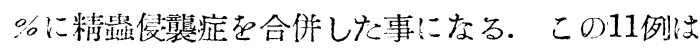
第 9 表に示した如く，24歲から55歲迄の人々で， 凡て副睪丸で，精管及び精䔩腺には1例もかる 變化芭發見していない。 
第 9 表 11例の精䖵侵襲症

\begin{tabular}{|c|c|c|c|c|c|c|}
\hline \multirow{2}{*}{ 䇛例 } & \multirow{2}{*}{ 年 龄 } & \multirow{2}{*}{$\begin{array}{c}\text { 部 位 } \\
\text { （何九も副荎丸） }\end{array}$} & \multirow{2}{*}{ 結核 性整化の有無 } & \multicolumn{2}{|c|}{ 精細管の奱化 } & \\
\hline & & & & 擴 張 & 精茧の停滞 & \\
\hline 1 & 29 & 右 側 尾 部 & $(-)$ & $(-)$ & $(-)$ & 兒發表 \\
\hline 2 & 55 & 11 & 副䙵丸頭部以外は & (t) & $(+)$ & (" \\
\hline 3 & 24 & 右 側 頭 & 副释丸頭部・精管が & (t) & $(t)$ & 末發表 \\
\hline 4 & 32 & " & 副重丸頭部以外は & $(+)$ & $(+)$ & " \\
\hline 5 & 26 & 側 尾 & $(-)$ & $(+)$ & $(-)$ & " \\
\hline 6 & 49 & 左 側 & 副票丸頭部以外以 & $(-)$ & $(-)$ & " \\
\hline 7 & 33 & 左 側 尾 & " & $(-)$ & (一) & "I \\
\hline 8 & 39 & " & 副要丸頭部・精管以外忙 (十) & $(-)$ & $(-)$ & " \\
\hline 9 & 24 & 側 尾 & $(-)$ & (-) & (二) & $"$ \\
\hline 10 & 25 & 左 側 尾 & $(-)$ & $(+)$ & $(二)$ & " \\
\hline 11 & 45 & 左 側 頭 & 副䙵丸頭部以外㤬 & $(-)$ & $(-)$ & "1 \\
\hline
\end{tabular}

副睪丸の中で冒された部位は，頭部が 4 例，尾 部が 7 例で, 又同時に精細管の撗張か 5 例に, 精 蛙の停舆が 3 例に見られた。要するに私のこの成 績は，副睪丸結核と臨床上殆んど鑑別不能とされ て居る精鼠侵裝症と云うものが決して珍らしくな い事者示しており，その臨床的重要性军書して いる.

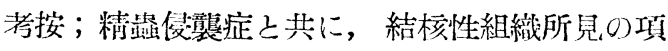
で述へたところの全く乾酪化した病桇に精罪のみ 笺存していていた所見在併せ考えると，結核の 時の精缆の態度は非常に興味深い. 結核性炎症の

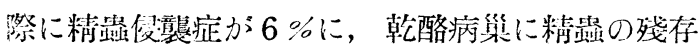

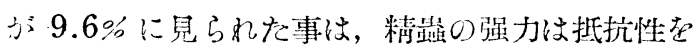
表している，郎ち棹踏は一般組織が結核性變化で 破壤されてもなお生存していたと考え得るのであ る. 精蠠侵寢症の病因は未げ不明であるが，その 發生には精蟲の停滞に加えて，精量を活生化する ある因子が必要の樣に思われる。私の結核症例で

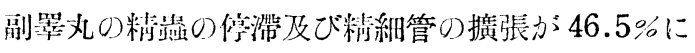
認められているが，精蚛鼬襲症は僅かに $6 \%$ に過 ぎないのはこの間の事情を物語つている。

最後に結核性副睪丸炎走思わせた 151 例の中に 剔除標本の精䄳の結果 11例, 郎ち $7.3 \%$ に精蟔俋 秥症を潑見した事實は，特别大書すべき事實であ る. 郎ち從來非常に稀己されていだ本症は決して 少くないもので，結核性副睪丸炎の診斷に際して 常に念頭におくべき疾患である事在忘れて永なら 存い。

\section{V. 精液檢查所見}

既に述べた如く，結核性副罢观炎の)單純性副睪 丸炎からの鑑別は，臨床的には篍外困難なもので ある。之れで私は精液所見がこの鑑男に何らかの 手脚りになるのではないかとの觀點から，精液檢 㮅を施行した。

結核性副罢丸炎の場合の档液の變化に就ては， 黑州(1949)が報告して府り，又 Ljunggren(1951) は精液所兒,特にその結核菌の有無が，值腸からの 指搠で中心部性器に何らの病變も認め得ない樣な 症例では，その診斷上重要な手排りになるを述へ

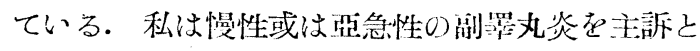
しだ患者の中で 61 例!二就て術前に粘液檢芷を施行 した.この61例の中で單側性のものは41例で，そ の中 6 例は射精がなかつた。. 又网側のものは20例 でこの中 8 例は射精がなかつた。故に實際に精液 さ得られたのは單側䍜患例の35例及び网側羅患例 ৩12例，合計47例であつた。この中結核例は單側惟 患例の26例及び兩側羅患例の10例，合訫 36 例であ り，非結核例は單側䍜患例 99 例及び网側羅患例 の 2 例の合計 11例であつた。なお精液は手滛によ り試驗管內に探取し，30分から1時間後にその量, 精罢の數, 運動狀態及び膿球及び赤血球の混在の

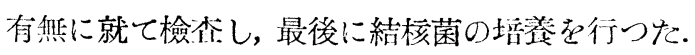

\section{A. 結核例36例の精液所見}

單側䍜患例 26例及び网側羅患例10例を別々にし て, 精液の量, 精站數, 運動狀態及び膿球及び 赤 血球の混入の有無を檢㮅しなふ， その成績は第 10 
第10表 結核例 36 例の精液所見

1. 精 液 量 (cc)

\begin{tabular}{c|c|c|c|c}
\hline & 例 數 & 最 多 & 最 少 & 平 均 \\
\hline 單側例 & 26 & 2.8 & 0.8 & 1.77 \\
\hline 兩側例 & 10 & 1.4 & 0.1 & 0.41
\end{tabular}

2. 精 䖵 數 $\left(1 \mathrm{~mm}^{3}\right.$ 中)

\begin{tabular}{l|l|l|l|l|l|l}
\hline & 例數 & 0 & $\begin{array}{c}1 \text { 萬 } \\
\text { 以下 }\end{array}$ & $\begin{array}{c}1 \text { 萬 } \\
2 \text { 萬 }\end{array}$ & \begin{tabular}{c}
2 萬 \\
\hline
\end{tabular} & 3 萬 \\
\hline 單 側 例 & 26 & 2 例 & 4 例 & 7 例 & 9 例 & 4 例 \\
\hline 兩 側 例 & 10 & 8 例 & 2 例 & 0 & 0 & 0
\end{tabular}

3. 運 動 狀 態

\begin{tabular}{|c|c|c|c|c|c|}
\hline & 例 數 & 良 好 & 稍 3 不起 & 不 良 & 運動せず \\
\hline 單側例 & 24 & 10例 & 10例 & 2 例 & 2 例 \\
\hline 兩側例 & 2 & 0 & 0 & 1 例 & 1 例 \\
\hline
\end{tabular}

4. 膿球及び赤血球の混入狀態

\begin{tabular}{l|c|c|c|c|c|c|c|c|c|c|c|c|}
\hline & 例數 & \multicolumn{3}{|c|}{ 膿 } & 球 & \multicolumn{3}{|c|}{ 赤 } & 血 & 球 \\
\hline
\end{tabular}

表の如くである. 文36例中 22 例に於ては更に結核

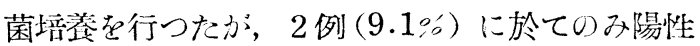
であつた。なお普通の塗抹䍒本では 1 例も結核菌 の證明に成功しなかつた。

B. 非結核例 11例の精液所見

單側䍜患例の9 例及び网側䍜患例の 2 例，合計 11例に就て，結核例の場合之同樣に單側及び网側 羅患例に分けてその梳液を調にたか， その成績は 第11表の如くであつた。

なお培卷は 5 例に行つたぶ，いずれも陰性であ つた.

考按；先す結核菌し詠明であるが，私の檢梵で

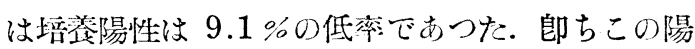
性は確實な診斷上の據點となるわ゙，方の㥞疗場合 は少なく，又その陰性の場合とい光ども結核を否 定するものではない。

その他の䜍種の所見に就て見ると，先す，棹液 量は一般に网側䍜患の時には單側躍患の場合より も少量の傾向があるが，結核性の場合は然らざる 場合よりる特に少量である傾向が見られた。精显
第11表 非結核例 11 例の精液所見

1. 踭液 量 (cc)

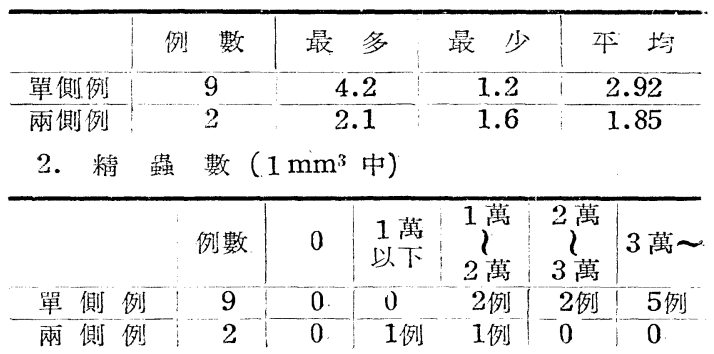

3. 運 動 狀 態

例數是好稍了不良不是運動せず

\begin{tabular}{c|c|c|c|c|c}
\hline 單側例 & 9 & 7 例 & 1例 & 1例 & 0 \\
\hline 兩側例 & 2 & 0 & 2 例 & 0 & 0
\end{tabular}

4. 澧球及び赤血球の混入狀態

\begin{tabular}{|c|c|c|c|c|c|c|c|c|c|c|c|}
\hline \multirow{2}{*}{\multicolumn{2}{|c|}{ 例基 }} & \multicolumn{3}{|c|}{ 膿 } & \multicolumn{2}{|l|}{ 球 } & \multicolumn{5}{|c|}{ 赤 血 球 } \\
\hline & & $(-)$ & $( \pm)$ & $(+)$ & $(t+)$ & $(\mathrm{ttt})$ & $(-)$ & (土) & $(+)$ & $(H)$ & $(\mathrm{HH})$ \\
\hline 則 & 9 & 0 & I例 & 2例 & 3例 & 3例 & 8例 & 1例 & 0 & 0 & 0 \\
\hline & 2 & 0 & 1例 & 0 & 1例 & 0 & 1例 & 0 & 0 & 0 & 1例 \\
\hline
\end{tabular}

數 $\left(1 \mathrm{~mm}^{3}\right.$ 中) は，結核例では44\%迄う零から 1 茧以下上云う少數值を示したのに反して，非結核 例の場合は，1萝以下は僅かに $9.1 \%$ 過ぎなか つた，精显出の運動狀態に關しては，結核性及び非 結核性共に网側䍜患例では不良のものが可成り多 いが，單側䍜患例では大體良好であり，結核例及 び非結核例の間には著しい敬異はなかつた。文膿 球の混入に關しては，その混入を全く見なか心の ものが，結核性たると非結核性たるとを間わず1 例もなかつた。これは副睪丸の炎症はすべて性器 の系統的炎症の一部分である事が多い點から容易 にうなづかれる非常に興味深い所見であるが，結 核性を非結核から區别し得る手脚りとはなり得な 6.

精业○形態に就ては，結核例及び非結核例，网 側例及び單側例を通じて正常のものが沿んどで， 形態の不良のものは見出されなかつた。

要するに結核菌陽性以外には結核性炎症を確實 に裹付けする精液所見はないが，その精聒數の減 少は結核性炎症に特有のものつ稼を，1 $\mathrm{mm}^{3}$ 中 1 
萬以下りもの法その疑いが濃厚と云い得る樣であ る。

\section{VI. 精囊腺レ線像}

男子性器結核の中で中心部，郎古精管膨大部及

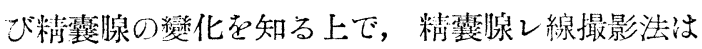
缺くべからざる捳のものであるが，從來泣，1）副 睪丸のみに注意が集中して此等中心部性器結核が 等闑に附されて局た，2)正常の精垔線し線像その ものが，腎盂レ線像と異り多種多樣である關係上 及びレ線像の變化を剔除標本に就て確實に比較檢 討し得なかつだ關係上，臨床上餘り重きをおかれ， ていなかつた。我國に於ては戶張寅之助(1932)及 び山本欽三郎・小息理一(1938)等が, 又最近では 大森淸一・加息英雄 (1952) が副睪丸結核の際の精 装腺し線像に就て述へているに過ざない，歐米で も漸く最近になつて22例の症例に就ての Staehler (1948)の經驗, 及び Couvelaire et Levey(1953) の記載等ここの問題が取上げられ出している.

私は，既に述へた料霓腺し線像の多樣性も，多 數例に就て術前に得たレ線像支副睪丸，粘裂腺剔 除術により剔除した標本と 比較檢討すれば，粘垔 腺レ線像も中心部性器結核の有無及び病戀の程度 を物語るものとして，診斷上の價值をもつ樣にな り，延いて泣手術を副睪丸の剔除のみに止めるか 精鞓腺の剔除迄擴大すべきかの判定の手脚りにな るのではないかとの考えのもとにっこのレ線撮影 法を施行した。

方法：Belfield and Rolnickの鼠徑切開法に上 b, 逆行性に $40 \% 0$ Moljodol を $2 \mathrm{cc}$ 注入し, 膀胱洗桬をして約 20 分後に恥骨上緗を焦點として 撮影した。

\section{A. 檢䄳材料}

118 例中 79 例に本法を施行した。この中 6 例は 精管の狹窄の第に造影劑の注入わ゙不能で撮影を斷 念した．注入叮能であつた73例中11例冲側の副 睪丸(睪丸)の剔除尼既に受けて府た㭧者であつた 窎に 1 側のみに施行したが，其の他牥な゙て网側 に行つた。

B. 檢杏成績

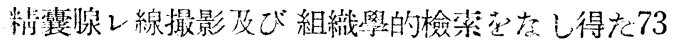

例中52例は結核性副睪丸炎で，殘りの21例悱結 核性副睪丸炎であつた。

（1）結核性副睪丸炎の場合の精䨋腺し線像：性 器結核之診斷された 52例の中で, 副睪丸のみに結 核性變化を認めて精管膨大部及び精露腺に變化を 認めないものは 10例(19.2\%)で，精管膨大部或は

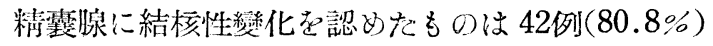
であつた。

i）副睪丸の結核性数化のみで，精管膨大部及び 精摆腺に結核性變化のないもの：第11圖に示した 如く, 䢬緣は圓滑で像の缺損或は空洞形成等の所 見のないものか９例あり，他の1例!結核性偻化

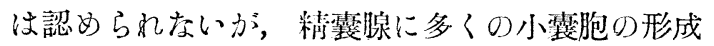
を見た。

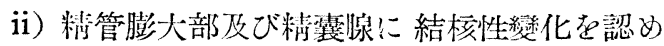

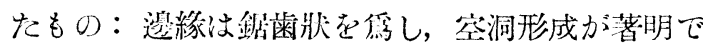

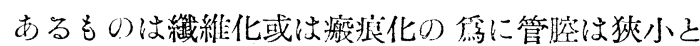
なり，更に商度のもの性粘管の影像のみでそれよ り中心部の性器の影像を見ないものもあつた（第 12. $13 ， 14 ， 15 ， 16 ， 17.18 ， 19$ (圖).なおこの中 に 1 側のみに本法を施行しな處，他側の料囊腺の 影像迄認めたものの(第17圖)が3 例, 又前立腺迄造 影偆劑が侵入した像を認めたものが1例あつた（第 18圖).

iii）造影劑の注入が不能で，撮影を斷念しだ 6 例は，いずれも榡管に高度の瘢症狹窄或は乾酪性 物質の无滿による通過障碍を認め，精管膨大部及 び精囊腺にはいすれも組織學的に著明な結核性綡 化を認めた。

( 2 )非結核性副睪丸炎の場合の精震豚し線像： 前に述べた如く，之に屬するものは21例あつだが， この中で中心部性器には著明の變化の認められな かつをもの(第20圖)が 15例，炎症性變化を認めた

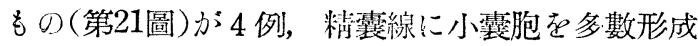
しているもの(第22圖)が 1 例，全く迠影矵の入ら なかつたものが1例であつた。

考按；ます料雯腺し線像の診斷的價值に就てで あるが，私が本法により得たレ線像と剔除棒本と を比較檢討して見な以上の結果から，その價値を 論じて見をい。 
結核性をると非結核性たるとを問わす， 乙線上 全く變化を見なかつを例に於て，組織學的に精囊 腺及び結管膨大部に變化を見た例は 1 例もなく， 之に反してレ線中心部性器に變化を見た例ではす べてに結核性或は非特異性炎症性變化を認めだ。 メレ線上中心部性器に結核性變化を認めなかつた ので，唯單に副睪丸剔除に止めた結核性副睪丸炎 の患者の中で，他日に他側の再發を來した例的 1 例もないが， 区對にレ線像には网側の精霘腺に結 核性變化壱認もさが，臨床的には 1 側の副睪丸の みにしか紗化を認めないまつに，1側の副睪丸， 精囊腺剔除を行つた 2 例 (第12圖, 第19圖)では, 夫々 6 カ月及び 1 年後に他側副睪丸の再發を見て 居る。更に又臨床的には 1 側の副睪丸のみに變化 支認もをが， レ線上网側の精凿腺及び精管膨大部 に變化を見たので，雨側の副睪丸，精囊腺剔除を 行つた例(第14圖)では，組織學的に檢索して見る と，臨床上變化のないと思われた側の副睪丸尾部 にも初期の結核性變化を認めた。

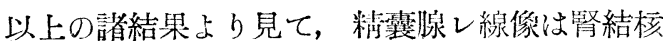
の場合の腎孟レ線像程の確實さはないが，中心部 性器の變化を臨木上診斷する上には相當の價值を 有し，性器結核に對して根治手術を行わんとする 時には必す術前に施行すべきもと考えられる。

次に精孁腺の非結核性の炎症の場合のレ線像で あるが，高度の炎症の場合は結核性變化と見誤ま る事もあるが，第21圖に示した如く，結核像に比 して凹凸も割に消かで，空洞形成等の變化は認め られす，注意哚く觀然すれば結核像との鑑別もそ う困難で治ない，又私の症例で，非結核例で造影 劑の全く入らない像が1例あつだが，之は注入技
術の未熟の第の結果と考えられる。

\section{VII. 根治手術の遠隔成績}

前に述心゙た如く，男子性器結核の根治手街とし

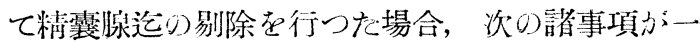
應問題となる. 郎ち，1) 術後の慺孔形成，2)他側 ○再發，3）術後の性生活及び 4）術後の前立腺の 變化等である。私は根治手獄を行つた 119 例に就 て，これ等の售事項を主にしてミの遠隔成績を詠 ベて見た.

1）乎衡伤の治癒：化學療法の進步と共にこれ の外科手術への應用が盛に行われる樣になつた現

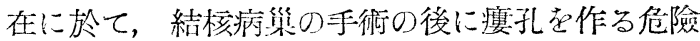
性は漸次少くなりつ〉ある，然し精囊腺結核に對

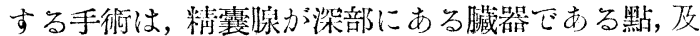
び當然結核に罹患していると考えられる前立腺に 對して，何ら手術を行わない點等から術後㾇孔形 成の钼いが一應考えられる。故に私は 119 例に就 て術後の手術仵の治癒及び 瘦孔の閉鎖期間を調へ て見た。第 12 表には結核性及び非結核性例を手術 々式別に分けて手䲞傷の治癔迄の日數を示した。 なお 119 例中手術死亡例の1例及び尿瘦を形成し た 2 例を除き，116例に就て檢梽した成績であ る.

郎ち $75.0 \%$ 15日以內に手術傷は完全に治瘾し 丈大部分の $94.8 \%$ 一次的に治瘾した。

尿瘦を作つた 2 例の中 1 例は尿管の損倠で，尿 管 S 爿腸呁合術を施行した。. 他の 1 例は膀胱を損 傷したので，尿道カテーテルの留置で尿瘻は完全 に治癒した。

2）他側の再發：單側手䘗患者60例中他側の再 破を見たものは 4 例(6.7\%) であつた。

第12表 手術傷の治療期間

\begin{tabular}{|c|c|c|c|c|c|c|c|c|c|c|}
\hline & 例數 & $\begin{array}{l}7 \text { 日 } \\
\text { 以內 }\end{array}$ & $\begin{array}{l}10 \text { 日 } \\
\text { 以內 }\end{array}$ & $\begin{array}{l}\text { 15日 } \\
\text { 以內 }\end{array}$ & $\begin{array}{l}20 \text { 日 } \\
\text { 以內 }\end{array}$ & $\begin{array}{l}30 日 \\
\text { 以內 }\end{array}$ & $\begin{array}{l}1 \text { 年 } \\
\text { 以丙 }\end{array}$ & $\begin{array}{l}1 \text { 年 } \\
\text { 以上 }\end{array}$ & $\begin{array}{l}\text { 一次的 } \\
\text { 治 瘜 }\end{array}$ & 云次的 \\
\hline 副粹丸（睪丸）剔除術……結 核 & 6 & 2 & 1 & 3 & & & & & 6 & \\
\hline ……非結核 & 5 & 3 & 2 & & & & & & 5 & \\
\hline 副睪丸 • 精囊腺剔除術……結 核 & 65 & 5 & 15 & 27 & 10 & 7 & 1 & & 60 & 5 \\
\hline$\cdots \cdots \cdot$ 非結核 & 24 & 1 & 6 & 9 & 7 & 1 & & & 23 & 1 \\
\hline 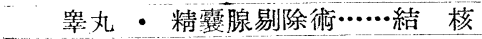 & 15 & 2 & 3 & 7 & 3 & & & & 15 & \\
\hline ……非結核 & 1 & & & 1 & & & & & 1 & \\
\hline 計 & 116 & 13 & 27 & 47 & 20 & 8 & 1 & 0 & 110 & 6 \\
\hline$\%$ & & 11.2 & 23.3 & 40.5 & 17.2 & 6.9 & 0.9 & 0 & 94.8 & 5.2 \\
\hline
\end{tabular}




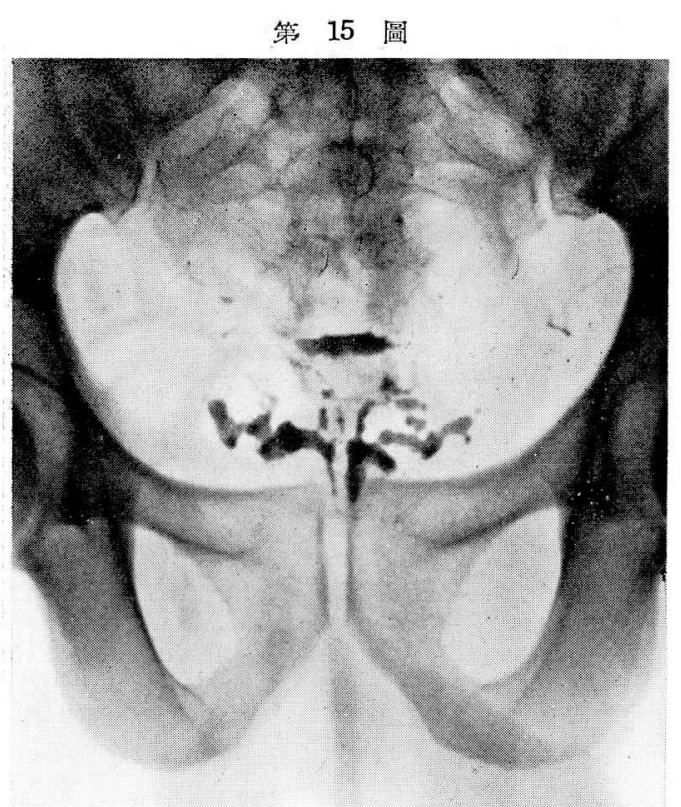

R

精囊腺に緎維化が著明に見ら

れ，陳舊性の變化を示した例.

第 17 圖

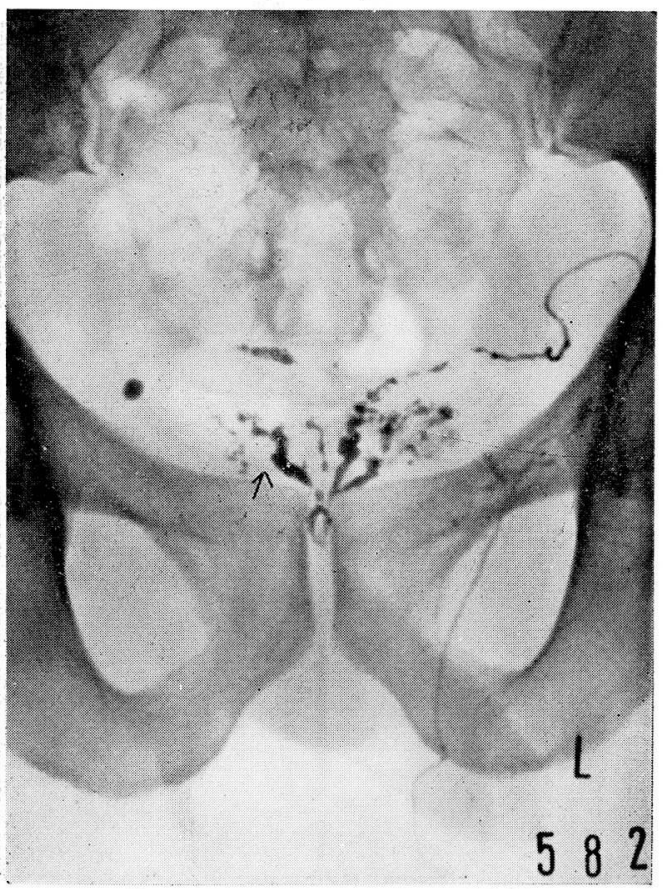

一側 (左側) 飞のみ施行した處, 他側 (右側) の精囊腺の影像 (矢印)をむ得られた例.

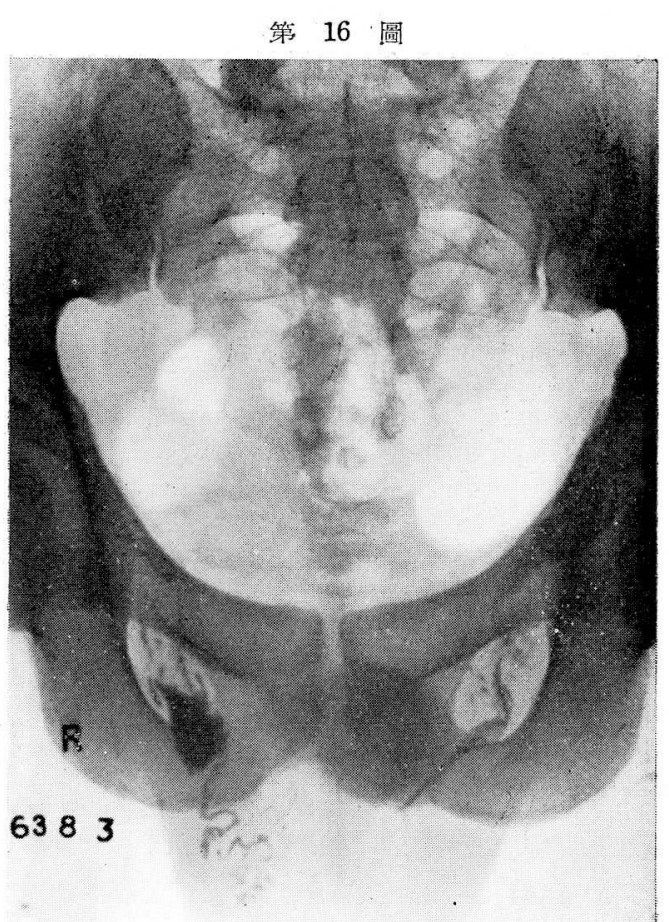

精管は高度の結核性變化の篇飞閉塞し て, 造影劑は中心部性器迄進入する事 が不能であつた例。

第 18 圖

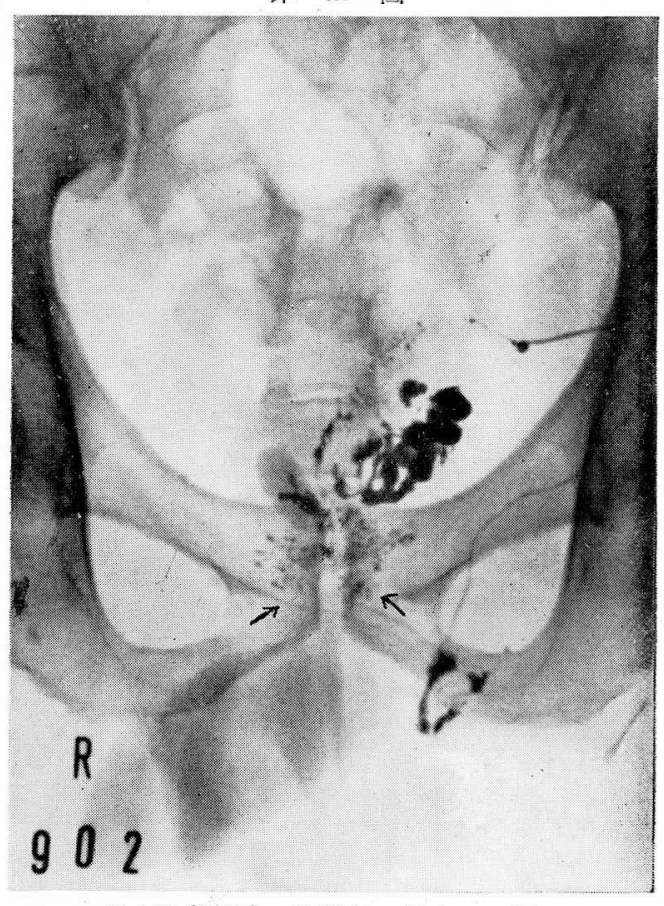

前立腺(矢印)に造影劑の侵入した例。 
第 19 圖

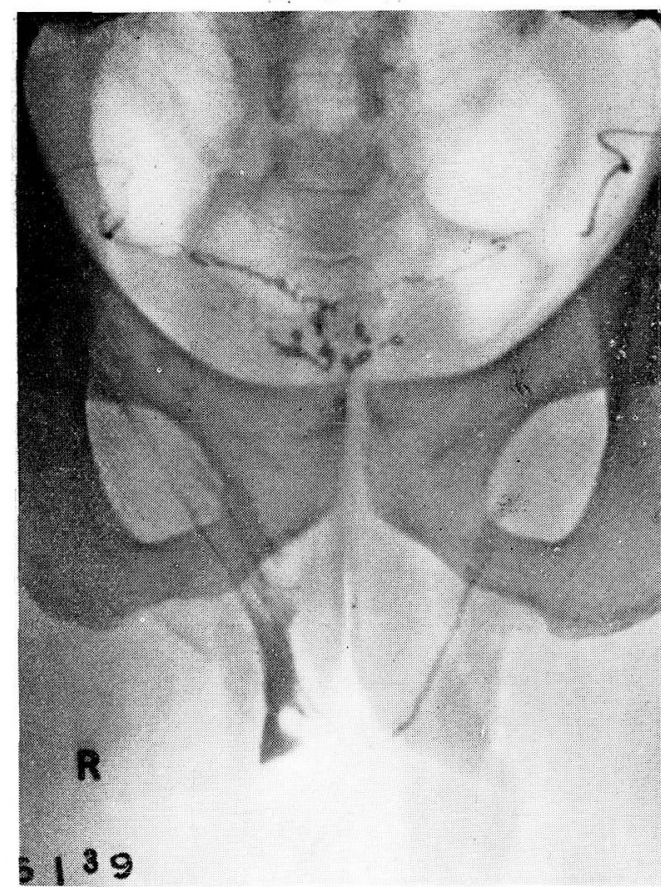

右副睪丸・精囊腺剔除後, 6

カ月“左側の再發老見た例。

第 21 圖

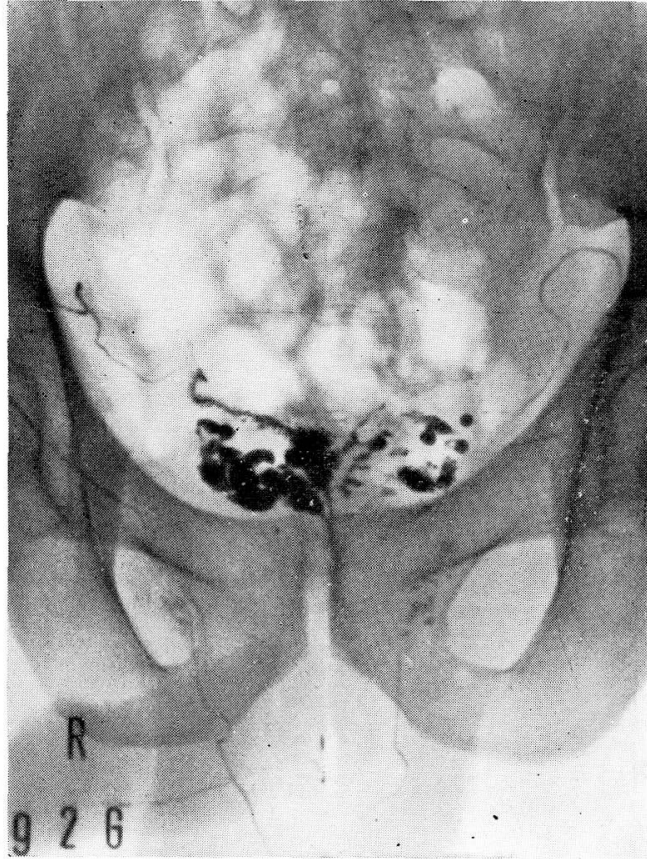

精賈腺に高度の炎症性變化

(化胶性炎症) 老見た例。
第 20 圖

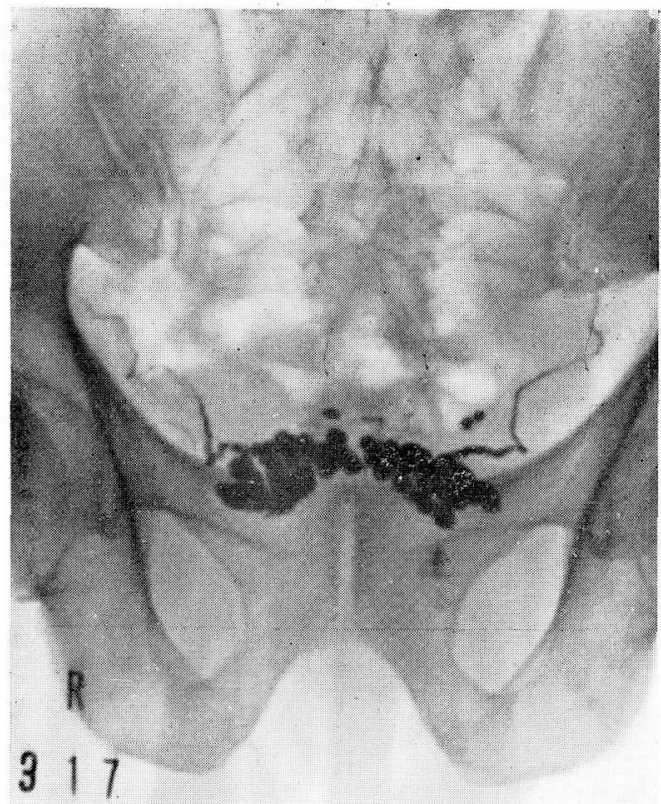

右副睪丸尾部に精蟲侵襲症孝認め る他活中心部性器法正常な例。

第 22 圖

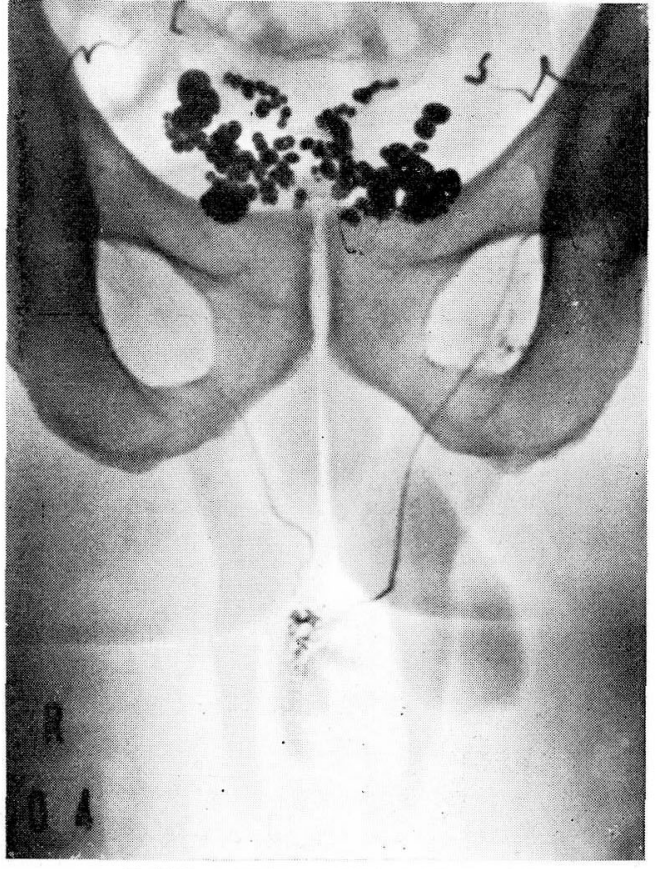

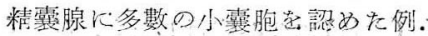


第13表 根治手術を弓けた 119 例中

82 例の術後の性的狀態

\begin{tabular}{|c|c|c|c|}
\hline & & $\begin{array}{c}\text { 兩 側 例 } \\
(34 \text { 例 })\end{array}$ & $\begin{array}{c}\text { 單 側 例 } \\
(48 \text { 例) }\end{array}$ \\
\hline \multirow{3}{*}{ 性 } & 術前上り塯加 & 0 & 2 例 \\
\hline & 變 化 な し & 14例 & 32 例 \\
\hline & 淞 3 減 退 & 14例 & 12例 \\
\hline \multirow[t]{3}{*}{ 慾 } & 著明に減退 & 6例 & s例 \\
\hline & 殆んぞ省し & 0 & 0 \\
\hline & 術前より塯强 & 1例 & 1例 \\
\hline \multirow{4}{*}{ 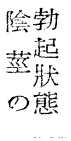 } & 戀 化 な & 24 例 & 39例 \\
\hline & 稍 3 減 退 & 6例 & 7例 \\
\hline & 著明飞減退 & 3 例 & 1例 \\
\hline & 始んど勃把せず & 0 & 0 \\
\hline \multirow{5}{*}{$\begin{array}{l}\text { 射及 } \\
\text { 精び } \\
\text { のそ } \\
\text { 有の } \\
\text { 無量: }\end{array}$} & 泪前より塯加 & 0 & 0 \\
\hline & 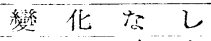 & 0 & 18 bi! \\
\hline & 科了減 少 & 4例 & 23 例 \\
\hline & 薯明に減少 & 14例 & 6 夘 \\
\hline & 殆んど射精吅寸 & 16例 & 1例 \\
\hline
\end{tabular}

3) 衎後い性生活：男于性器結核力20藏代灭心゙

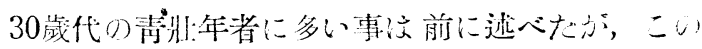

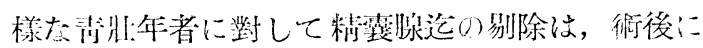

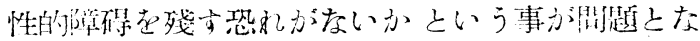

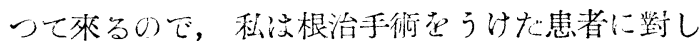

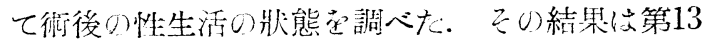
表の如くである。

師ち，网側手術例の34例及び單側手術例の48 例，合計 82例に就て調べたか，性惢及び㓌聴の勃

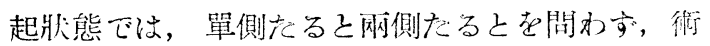
前上稌り變化がないものぶ多數寺占めていた。し

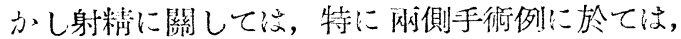
射料量の著明に減少したもの或は全くはないもう ぶ30例(88.2\%)に見られた。

4) 根治手術後の前立脉の變化：

男子性器結核に於て，前立腺の結核䍜患涪は剖 檢例!二就ての檢㮃では最も高率を示している事は 既に述へたが，臨床的に前立腺迄の别除在行う事 が種々の問題を有している今日に於て，精露腺迄

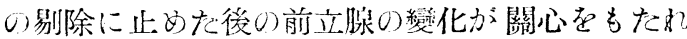
る留題となつて來る。副睪丸のみの剔除のみで殘

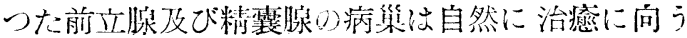
場合方多いという事恃，Barney，V. Bruns，Kocher, Menville and Priestley 等の提唱している 成它てる。

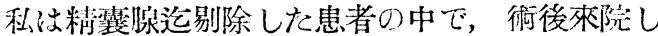
$た 29$ 例に就て，前立腺の變化を直腸よりの指診に

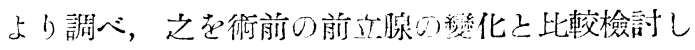
て見た

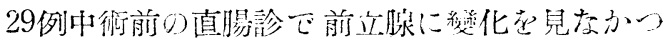

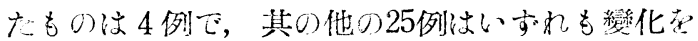
認为ていた，術前變化を認めなおつた 4 例は，根 治二北後も前立朓には直腸診的に全く戀化はなか つナ゙. 街前に前立腺に變化苍見た 25 例の中の 2 例

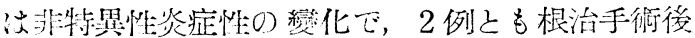
は列んぞ正常に亦えつていた。殘りの23例は，い

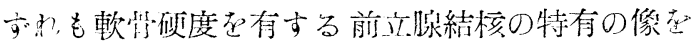

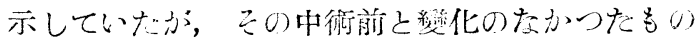
招2例 (8.7\%)，軟化の著明のものか６例（26.1

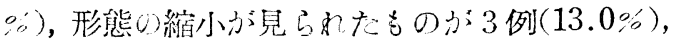
軟化灭び縮小が認められたものが12例(52.2\%)た

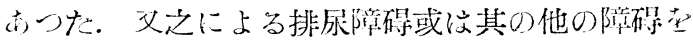
訴兄たものは 1 例をなおつた。

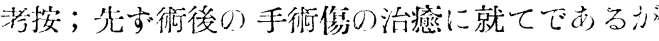
第13表に示した如く，119例中 $94.8 \%$ 沙一次的に

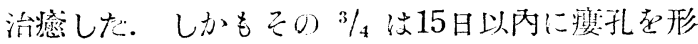
成する事なしに完全に治癒している。この傾向仿 結核性の場合も非結核性の場合も大體同じで，結

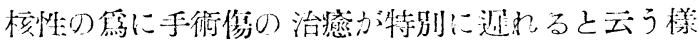
な傾向は見られな和つた。この事上り，事當な化

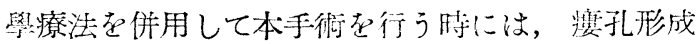

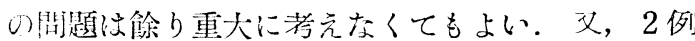

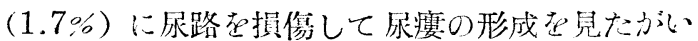

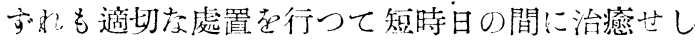
めており，現在我々の敎室では精管に直接沿つて 剩離して行く關係上，尿管方何處にあるか制らど

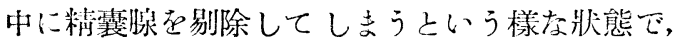
糊管に沿つて手術老進めさえすれば，この點も文 䦤题とならない。

次に他側の再發の䦩題である。しばしば述べた 如く, 男子性器結核は系統的疾患で, 性器各臟器 ぶ相次で冒されるものである。この斉に 1 側を手 術してもその後で他側の再發を見る事が多く，こ の意味で根治手術が重要性をもつて來る。

從來性器結核に對して行われて來た副䍘丸（罢 丸）のみの剔除の場合の再發率を文獻的に見る之。 第14表の如くである. 
筑14表 副囯丸（睪丸）のみの剔除の場合の他側の再發

\begin{tabular}{|c|c|c|c|c|c|}
\hline \multicolumn{6}{|c|}{ 副金丸剔除後の再發 } \\
\hline Wildbolz & 68例中 & $15 \%$ & 石 田 & & $1.35 \%$ \\
\hline Marinesco & 33例中 & $6 \%$ & 小池・大森 & 13例中 & 0 \\
\hline $\begin{array}{l}\text { Delore et } \\
\text { Chalier }\end{array}$ & & & 河石・岡本 & 14例中 & $14.3 \%$ \\
\hline $\begin{array}{l}\text { (nach } \\
\text { Walthard) }\end{array}$ & 81 例中 & $18.5 \%$ & 山 & & $16.4 \%$ \\
\hline Rydgaard & 58例中 & $5.5 \%$ & 石川・李 & & $14.3 \%$ \\
\hline
\end{tabular}

牛除鼻術後の再發|| 除睪術後の再發

\begin{tabular}{|c|c|c|c|}
\hline V. Bruns & 78 例中 $23.0 \%$ & Wildbolz & $30 \%$ \\
\hline V. Gaza & 63 例中 $28.5 \%$ & 石 田 & $21 \%$ \\
\hline Schwartz & 62 例中 $37.0 \%$ & 河石 - 哃本 & $28.6 \%$ \\
\hline Reineck & 49 例中 $30.0 \%$ & 石川・李 & $28.6 \%$ \\
\hline Brdndes & 60 例中 $30.0 \%$ & 小 & $29.9 \%$ \\
\hline
\end{tabular}

郎ち，除睪術後及び滁睪術後は夫々 $20 \%$ 或は $30 \%$ 以上の再發を見ており，副睪丸剔除後でも少 數例に就ての報告では低い再發率を示しているも のもあるが，多數例の報告では大體 $10 \%$ 內外の再 發を見ている.

私の症例では，單側手術例60例中他側の再發を 見たのは 4 例 $(6.7 \%)$ で，これを第14表に示した 諸家の再弡率と比較して見ると，副睪丸剔除後の 再發に比べては決して優れているとはいえないか～ 私のこの再設率は副睪丸・粘囊腺，4除睪・精囊 腺及び罢丸・精栱腺剔除をすべて合した場合の再 發率であり，かつる觀點より私の再發率を見る時 は，從來の副睪丸或は睪丸のみの剔除に止めた場 合上りはるかに優れている. 更に私の症例中再發 を示した 4 例に就て見ると，この中の 2 例糊霆 腺レ線像の項に於て述べた如く，衍前の精䨢腚レ 線儌では中心部性器には明らかに結核性變化を認 めており(第 12 圖及び第19圖), 虽然兩側同時に剔 除すべき患者であつだ。

他の1例は糊要腺し線掫影は行わなかつたが, 直腸診的には中心部性器に著明な网側性の變化を 認めていた。

又術前の精琵腺し線像で他側の中心部性器には 何等結核性變化を見ない症例で㳉，䍜患側の副罢 丸(睪丸)，精裂腺剔除を行つてから今日迄他側の 再發を見たものは 1 例もなかつた。この事より我 々の行つている副睪文, 羂丸精靁腺剔除術は, 確 實な彰斷の下に行いさえすれば，男子性器結核に
對する最も理想に近い根治手術となり得る。

術後の性生活に關する諸問題は第 13表に示した 如く，性愍及び㓌菜の勃起狀態は，一側剔除たる と兩側剔除たるとを䦐わず，術前と比較して心咆

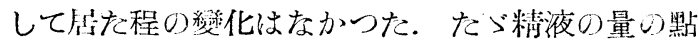
では，特に州側剔除例では，已の88.2\%が著明に 減少したが或は全く射精がなかつた。

最後に精裂娦迄の剔除を行つた後の前立腺の戀 化である．術後直晹診を行い得た29例中畐前に二前 立腺に變化を認めた25例に就て見ると，この中の 23例(92\%) が軟化或は縮小を示していた。こい樣 な直腸診の所見のみから直らに前立脉の治癒芷 定する事は出來好ふ，少くとも臨床的立場々り見 た處では大部分が治癒に向つており，前立胍に對 してはこれ以上の手術的療法を加える必要识ない ものと考える。

\section{結語}

私は 1950年 7 月以後の 3 力年間に於て，結核の 疑いの濃厚慢性或は亞急性の副器丸炎定主訴亡 して新渴大學醫學部泌尿器科に入院した 119 例心 患者に就て，副睪丸を中心こして檢螺を行つて， 次の事實在知つた。

\section{1. 手術：}

原则的にはVillard 0) 鼠徑・旁直腹筋切開:

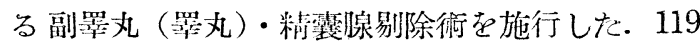
例中网側例が33例で, 實際に剔除した包數は152包

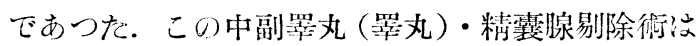
131回 (86.2\%)，副睪丸(睪丸)剔除術は19回 (12.5

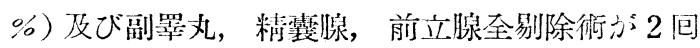
(1.3\%) であつた。

2. 結核性副睪丸炎心頻度：

151 例の剔除標本に就て組織學的檢菜苾行つた が，この中 114 例 $(75.5 \%$ )が結核性副㖕丸炎で志 る事灻確めた。

\section{3. 臨床像：}

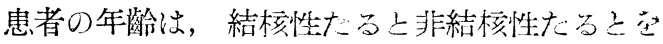
問わず，20歲代及び30歲代が最も多數で，79.7\% を占めていた。网側羅患例か：55 例 $(46.6 \%$ )こ， 單側例では著明な左右の筷異は見られながた。 尿路結核合併したるのは36例(30.5\%)で，こい 中23例は网側䍜患例であつた。

4. 組織斆的檢岱の成績 : 
a）結核性變化を認めたものつ中で，變化が副 睪丸から精裂腺艺全部，或は大部分の部位に見 られたものは79例(69.3\%)に達しており，結核性 變化冷副睪丸を中心として見ても，系統的疾患の 容相を呈する事が多い. 性器各部の結核䍜患率は, 症例の少ない前立腺を除外すれば，副睪丸尾部の $92.1 \%$, 精垔缐の86.1\%，精管膨大部の84.0\%，粘 管の68.4\%，罢丸の $57.1 \%$ 及び副睪丸頭部の33.3

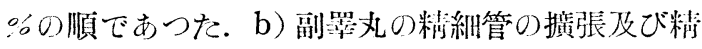

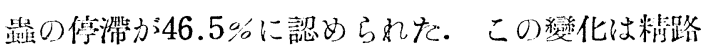
のより下部の何處かに通過障碍の存在支暗示する 興味ある所見である。）精管の縞化は他の部に比

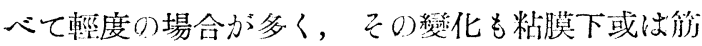
首に見られるものが多かつたが，この样な所見は 結核性たると, 非結核性たる己を間わず，共通の戀

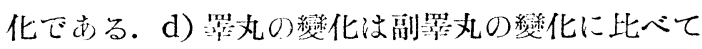

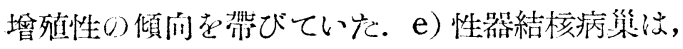
化學療法後に特別の治瘾傾向を示さなかつた。 f) 血行性に結核菌を注:入した家鬼に就ての實驗によ れ败，結核菌が最も多く侯入する部位は前立腺，骂 丸及び副䍘丸尼部であるのに反して，臨床例では 結核菌が最も多く發見された部位は副睪丸尼部， 战管及び䊑裂腺であつた。この事實は一方では性 器の結核に對する抵抗性の相造から血行性の結核 菌の信入率と發病率とは異なることを示すと共に 他方臨床的には管腔性感染が非常に重要な役割を 演じている事を示唆している，又精露腺孔副睪丸 の間の偻化は精管の粘膜下，筋層或は周圍の淋巴

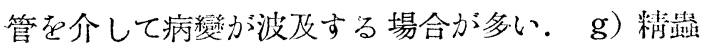
浐警症か11例(7.3\%)に見られた。郎ち本症は決 して稀な疾患ではなく，結核性副睪丸炎の鑑別揨 断上常に考虑すべき疾患の1つである.

5. 精液所兌：

粘液所見は一般的にいつて，結核性と非結核性 との場合で著明な养異はない。唯精量出數の減少は 結核に特有の所見である傾向か强い。結核菌は培 賸上僅かに $9.1 \%$ に陽性であつたにすぎない。故 にこの培美成績海床診斷上除り有用ではない。 その陽性は性器結核を確定するがその㓌性は結核 否定する荘素とはならない。

6. 精琵腺乙線像：

算血像程の正確ささないが中心部性器の變化を
臨床上渗斷する上には相當の價值存有し，性品結

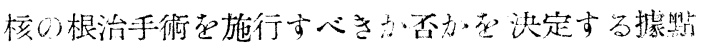
となる。

\section{7. 嗃隔成績:}

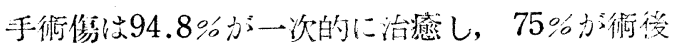
15日以內に手術偤は瘦孔走形成せず治癒した。

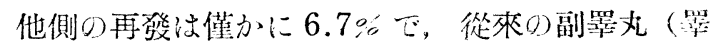
丸）のみの場合に比較して優れている. 術後の性: 生活虫，射战量の減少在除いて蚁，術前に比心

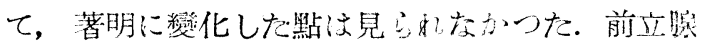
は92\%か㩰快していた。

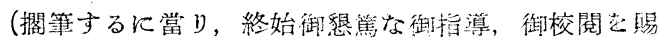
つた恩師楠敉授に厚く感謝の意老表才万次第である。

\section{文獻}

1) 阿部禮男：日泌尿會誌，42，240， 1951. - - 2) 阿部禮男, 向山敏幸: 臨床皮泌，6８， 88，1952.-3? 赫崎策義, 大崎完一, 島田猪一郎, 谷內泰寬：臨床, 3 , 154，1950. 一个) 秋山一雄：日泌尿會誌，31，57， 1941, -5) Bachrach, R.: Z. urol. Chir., 11, 114, 1923. -6) Baker, W.J. \& Graf, E.C.: J. Urol., 66, 254, 1951. -7) Barney, J.D.: J. Urol., 10, 81, 1923- J.A.M.A. 63, 2274, 1925.-8) Barney, J.D., Watson, J.L. \& Elliott, S.: Am. J. Surg., 10, 84, 1930. -9) Belfield, W.T.: Surg. Gyn. \& Obst., 16, 569, 1913-J.A.M.A., 61, 1867, 1913. -10) Belfield, W.T. \& Rolnick, H.C.: J. Urol., 16, 73, 1926. -11) Cabot, H. \& Barney, J.D.: J.A.M.A. 61, 2059, 1913. -12) Couvelaire, R. \& Levey, C.: J. d' Urol., 59, 447, 1952.-13) Cunningham, J. H.: Tr. Am. Urol. Ass., 10, 168, 1916. (quoted by Barney, J.D. et al: Am. J. Surg., 10, 84, 1930). -14) Felsenreich, F.: Dtsch. $Z$. Chir., 224, 383, 1930. - 15) Friedmann, G., Shargel, G. \& Litvak, H.: J. Urol., 68, 523, 1952. -16) Friedman, N.B. \& Garske, G.L.: J. Urol., 62, 363, 1949.-17) Greenberger, A.J. \& Greenberger, M.E.: J. Urol., 67, 222, $1952 . \quad$-18) Herman, L.: J. Urol., 61, 122, 1949.-19) 一井 治夫：日結，11，62，1952. 一20）书门篤二, 木村浩 三郎：日泌尿會誌，36，107，1943. 一21）求川篤 二, 峰永六郎：外科， 3, 262， 1939. -22) 市川籰 二, 大越正秋：臨床， 2，566，1949. 一23) 稻田袎： 皮紀要， 31，1，79，429，1938- 32，71，1938. 24）石田清夫：東京醫事新誌， 2609，11，1929. 25）石川宗一, 李杜傑：日外誌, 42, 1564, 1941. -26）岩田正二, 龜井義明：第190回日本泌尿器科學 會東宗地力會, 1953. - 27) Jones, R.F.: J. Urol.,

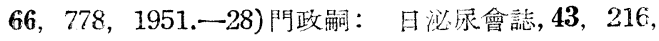
1952. 一29) 河石九二夫, 阔本一男：外科，2，525， 
1938. 一-30)小池藤太郎, 大森三㐎：日泌尿會誌，21, 238，1932. - -31) 小山征助：日泌永會誌， 39，57, 1948. 一 - 32) 黑田和夫：臨床皮泌， 3， 7, 1949.33）楠隆光：臨外，6，247，1951.—乎術，5，361, 1951. -34)Lattimer, J.K., Stearns, W.H., Amberson, J.B., J., Schwartz Goodman, R. \& East, W. J. Urol., 60, 974, 1948. - 35) Lattimer, J.K., Herizberg, A., Harper, J., Berman, M., Bradley, D. \& Veenema, R.: J. Urol., 67, 750, 1952. -36) Ljunggren, E.: Z. Urol. 44, 95, 1951.-37) Medlar, E.M., Spain, D.M. \& Holliday, R.W.: J. Urol.,61, 1078, 1949. - 38) Menville, J.G. \& Priestley, J.T.: J. Urol., 40, 66, 1938. -39) 中 河義夫：日泌沓會誌，36，339，1944.-40）日東寺 浩, 豐田泰: 第185可日本泌尿器科學會東京地方會, 1953. 一41）能勢博之, 工藤久之：日泌尿會誌, 18, 430，1929. 一42) 大森声一, 加島英雄：手䔎, 6, 593. 1952. - 43) 大森周三郎, 齋藤英一: 臨床皮 泌, 6, 116, 1952. - 44) Orsós, F.: Virchow. Arch., 307, 352, 1941. -45) Riegór, I.T. \& Fuller, R.H.: J. Urol., 69, 819, 1953.-46) Rydgaard, F.: Arch. Klin. Chir., 123, 758, 1923,-4i)
坂口弘治郎, 大森周三郎：日泌尿會誌, 24, 547, 1935. 一48）坂野於兔，松本忠夫，手束份：日泌旅 會誌, 44, 372, 1953. 一 49) Scardino, P.L., Kelley, R.A. \& Scott, W.W.: J. Urol., 63, 698, 1950. - 50) Schultz, Ph. J.: Z. Tbk., 36, 81, 1922. -51) Schwarz, E.: Arch. Klin. Chir., 127, 474, 1923.-52) Silva de Assis, J.: Z. urol. Chir., 43, 427, 1937-J. Urol., 68, 747, 1952. -53) Simmonds, M.: Dtsch. Med. Wschr., 1915, 120. -54) Staehler, W.: Langenbecks Arch. u. Dtsch. Z. Chir., 261, 403, 1948.-55) Sussig, L.: Dtsch. Z. Chir., 165, 101, 1924. 一56) 田村一, 酒井俊司, 岡

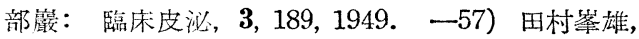
長谷廣：臨床皮泌，7，339，1953. - 58) Taylor, J.A.: J. Urol., 61, 806, 1949. 一59) 戶張寅之助: 日泌尿會誌：21, 71, 1932. -60）豐田泰：日泌尿 會誌, 44, 433, 1953. -61) Walthard, H.: Handbuch d. Urol., 1927, 153. - 62) 'Wildbolz, H.: Z Urol., 30, 433, 1936.一63) 山本欽三郎, 小島理一: 皮泌誌, 44, 487, 1938. -64) Young, H.H.: Surg. Gyn. \& Obst., 26, 375, 1918. -J.A.M.A., 104. 722, 1935. 